\title{
Analyzing the role of periplasmic folding factors in the biogenesis of OMPs and members of the type $V$ secretion system
}

\author{
Gustavo Bodelón\#, Elvira Marín\# and Luis Ángel Fernández* \\ Department of Microbial Biotechnology, Centro Nacional de Biotecnología, Consejo \\ Superior de Investigaciones Científicas (CSIC), Campus de Cantoblanco, 28049 Madrid, \\ Spain.
}

Running title: Periplasmic chaperones in OMPs and T5SS biogenesis

Keywords: periplasmic chaperones/ Disulfide bonds/ autotransporters/ intimin/ $\mathrm{OMP}$ / type V secretion systems/ E. coli

\# These authors contributed equally to this work

${ }^{*}$ Corresponding Author:

Dr. Luis Ángel Fernández

Centro Nacional de Biotecnología - CSIC

Darwin 3

Campus de Cantoblanco, UAM

Madrid, 28049 (Spain).

Phone: +34 915854854

Fax: +34915854506

E-mail: lafdez@cnb.csic.es 


\section{Summary}

The outer membrane (OM) of Gram-negative bacteria is highly packed with $\mathrm{OM}$ proteins (OMPs) and the trafficking and assembly of OMPs in Gram-negative bacteria is a subject of intense research. Structurally, OMPs vary in the number of $\beta$-strands and in the size and complexity of extra-membrane domains, being extreme examples the members of the type $V$ protein secretion system (T5SS), such as the autotransporter (AT) and intimin/invasin families of secreted proteins, in which a large extracellular "passenger" domain is linked to a $\beta$-barrel that inserts in the OM. Despite their structural and functional diversity, OMPs interact in the periplasm with a relatively small set of protein chaperons that facilitate their transport from the inner membrane (IM) to the $\beta$-barrel assembly machinery (BAM complex), preventing aggregation and assisting their folding in various aspects including disulfide bond formation. This chapter is focused on the periplasmic folding factors involved in the biogenesis of integral OMPs and members of T5SS in E. coli, which is used as a model system in this field. Background information of these periplasmic folding factors is provided along with genetic methods to generate conditional mutants that deplete these factors from $E$. coli and biochemical methods to analyze the folding, surface display, disulfide formation and oligomerization state of OMPs/T5SS in these mutants. 


\section{Introduction}

The biogenesis of OMPs initiates in the bacterial cytoplasm and encompasses their translocation across the IM to the periplasm via the Sec pathway before final folding and assembly in the $\mathrm{OM}$ by the $\beta$-barrel assembly machinery (BAM complex) (1-4). OMPs contain an N-terminal cleavable signal sequence that is recognized by the SecYEG translocon. In the cytoplasm, OMPs bind to SecB, which maintains them in a fully unfolded state until they reach the translocase that drives translocation of the polypeptide across the IM in an unfolded conformation (5). Subsequently, in the periplasm the polypeptides are assisted by different types of folding factors and escorted to the BAM complex for OM assembly $(6,7)$.

The identification of extracytoplasmic folding factors started in the early nineties with the discovery of disulfide bond formation by DsbA and the peptidylprolyl-cistrans-isomerase PpiA $(8,9)$. In 1996, as a result of the search for proteins that decreased the $\sigma \mathrm{E}$-dependent response constitutively induced by the accumulation of misfolded proteins in the periplasm, SurA, FkpA and Skp proteins were identified as periplasmic folding factors (10). In that same year, SurA and Skp were shown to bind and assist the folding of OMPs, confirming their function as molecular chaperones $(11,12)$. Since these initial discoveries, the work of the past decades has led to the identification of numerous periplasmic folding factors, the obtention of their crystalized structures and elucidation of the molecular mechanisms and events that participate in the biogenesis of OMPs $(1-4,13-17)$.

The periplasm contains numerous folding catalysts, that in some cases present overlapping functions: chaperones for preventing undesirable off-pathway interactions or aggregation of improperly folded polypeptides (e.g. Skp, SurA, DegP, HdeA and Spy), peptidyl-prolyl cis/trans isomerases (PPIases) catalyzing cis/trans isomerization of proline peptide bonds in proteins (e.g. SurA, FkpA, PpiA, PpiD), oxidorreductases that mediate the formation and exchange of disulfide bonds (e.g. DsbA, DsbC), and proteases (e.g. DegP). These proteins assist the folding of OMPs but also other types of periplasmic and membrane-associated proteins. The structure and function of the above mentioned folding factors have been reviewed recently $(3,13,17,18)$. In addition to the above-mentioned proteins, the periplasm of Gram-negatives contains other types of folding factors that are specifically dedicated to assist the subunits of surface organelles (e.g. fimbria, pili, etc.). The function of dedicated periplasmic chaperones of fimbrial subunits (e.g. PapD, FimC) has been reviewed recently (19).

The periplasmic chaperones are also involved in the protection of OMPs under stress conditions. Envelope stress induces the accumulation of misfolded or aggregated OMPs in the periplasm, which is lethal to the cell. To avoid cellular damage, Gram-negative bacteria have evolved signal transduction pathways (e.g. $\sigma \mathrm{E}$ and $\mathrm{Cpx}$ systems) that sense and respond to stress, in part by upregulating periplasmic folding factors (e.g. SurA, Skp, FkpA) and proteases (DegP) $(13,20)$.

The SurA polypeptide is composed of four domains: an N-terminal domain, two central PPIase domains (PPIase 1 and 2) of the parvulin family and a short Cterminal domain (21). The $\mathrm{N}$ - and the $\mathrm{C}$-terminal regions have chaperone activity, whereas the PPIase activity exclusively resides in the PPIase domain 2 (22), the PPIase domain 1 could be responsible for substrate selection because it was shown 
to selectively bind peptides that are rich in aromatic residues and characteristic for OMPs (23). SurA has a strong preference for binding Ar-X-Ar tripeptide motifs, commonly found in the C-terminus of OMPs, being Ar any aromatic and X can be any residue (24). SurA binds OMPs immediately after they leave the Sec translocon before signal sequence cleavage (25), and it has been shown to interact with the AT serine protease EspP from enterohemorrhagic E. coli (EHEC) 0157:H7 (26). It is also the may chaperone assisting folding of EHEC Intimin (27). Interestingly, SurA was also detected in association with BamA, the central component of the BAM complex $(26,28,29)$. These and other experimental observations (30), have led propose that SurA binds unfolded OMPs in the periplasm and transports them to BamA, where they are taken by the periplasmic polypeptide transportassociated (POTRA) domains through a $\beta$-augmentation mechanism. SurA and BamB have been also suggested to function in the same folding pathway of numerous OMPs $(25,31-33)$. Recently, Ricci and collaborators have shown that defects in OMP assembly caused by mutations of BamA or BamB can be corrected by gain-of-function mutations in the PPIase 1 domain of SurA, suggesting that the activity of SurA could be regulated by interactions between its PPIase 1 domain and BamA/BamB (34).

Skp is a small protein of about $17 \mathrm{kDa}$ that forms a homotrimer, which binds its substrate in a 1:1 stoichiometry. The crystallized trimer shows a structure with three $\alpha$-helical tentacles protruding from a basal trimerization interface forming a central cavity that holds substrates protecting them from aggregation $(35,36)$. Recent structural and biophysical analysis showed that Skp forms transient interactions with OMP polypeptides that are sequence unspecific and weak, thus allowing Skp to interact with a broad range of different substrates. The authors speculate that the flexibility of the interaction between Skp and the OMP substrates could also facilitate its release to a downstream receptor in the Bam complex bearing higher affinity for a particular sequence in the OMP (37). In vivo, Skp binds unfolded OMPs while they are still engaged in translocation through Sec translocon (38, 39). Site-specific photocrosslinking experiments have demonstrated that Skp interacts with the AT EspP, which is at the same time engaged with components of the BAM complex $(26,40)$. Intriguingly, although Skp was shown to interact with more than 30 envelope proteins of E. coli (40-42), to date no OMP appears to depend preferentially on Skp for folding in E. coli (43). However, recent experiments in Neisseria meningitidis demonstrated that two major OMPs, PorA and PorB, use Skp preferentially (44), and Skp was demonstrated to be required for the efficient assembly of the AT IcsA in Shigella flexneri (45).

DegP belongs to the serine proteases high temperature requirement (HtrA) family and is considered both a chaperone and a protease (46-48). The DegP monomer is composed of a $\mathrm{N}$-terminal trypsin-like protease domain and two C-terminal PDZ domains allowing DegP to recognize its substrates (47). DegP exists in different oligomeric forms, ranging from a 6-mer to a 24-mer with a 3-mer as the fundamental building block. In the presence of the substrate, the homotrimers further oligomerize via PDZ1-PDZ2 interactions into oligomeric cage-like structures that exhibit both protease and chaperone activity (48-53). The likely reason for the different oligomeric states of DegP is to provide functional control of its efficient but rather indiscriminate proteolytic activity (52). DegP is upregulated 
by the $\sigma \mathrm{E}$ and the Cpx systems in response to heat shock or to other envelope stresses performing both the antagonistic functions of protein repair and degradation (13). DegP was proposed to act as a molecular chaperone mainly based on the observations that captures folded OmpA and OmpC (48). Interestingly, complementation experiments with a DegP protein mutated in its protease active site (DegP-S236A) rescued full expression of EspP in a degP mutant strain with severe reduction of EspP secretion (42). In the case of EHEC Intimin, DegP was shown to act mainly as a protease to degrade unfolded polypeptide in the periplasm (27). Recently, Ge and collaborators used genetically incorporated non-natural amino acids for the identification of DegP substrates by photocrosslinking and co-purification in E. coli cells, and identified several OMPs including $\mathrm{OmpC}, \mathrm{F}, \mathrm{A}, \mathrm{X}, \mathrm{W}$ and $\mathrm{NmpC}$ (54). In this work, the authors stated that DegP mainly functions as a protease with hardly any appreciable chaperone function (54).

Two pathways have been shown to assist the biogenesis of OMPs: SurA and Skp/DegP pathways. Genetic analysis performed in E. coli indicated that bacterial cells that lack either SurA or Skp are viable, but cells that lack SurA and Skp or SurA and DegP are not viable (synthetic lethality). This discovery suggested that DegP/Skp and SurA operate in parallel pathways that are functionally redundant (55). In E. coli, OMP assembly preferentially depends on SurA, suggesting that the DegP/Skp pathway functions as a backup to rescue OMPs that fall off of the SurA pathway, particularly under stressful conditions $(27,28,43)$. The major arguments in favor of this hypothesis is that whereas strains lacking surA have a decreased OM density (28) and are hypersensitive to detergents and hydrophobic antibiotics, an indicative of OM perturbations (43), deletion of the $s k p$ gene only leads to a moderate reduction in OMPs (56) and shows a much less severe phenotype than surA mutants (28). In an alternative model, it has been proposed that Skp and SurA cooperate sequentially in the same pathway (57). Interestingly, it has been reported that both SurA and Skp perform distinct roles in the biogenesis of the essential OMP LptD, indicating that both pathways might act in concert to efficiently assemble certain OMPs (58). Despite of the numerous findings, the exact role of the various players involved is far to be clear (59). It is still difficult to provide a detailed description of the role of the periplasmic folding factors that is universally applicable to all OMPs. The preference for periplasmic folding factors seems to be protein and potentially species-specific (14).

Besides SurA, the periplasm of E. coli contains several other PPIases: PpiD and PpiA, whose function in OMP biogenesis remains to be clarified (17), and FkpA. FkpA belongs to the FKBP family of PPIases, presents general chaperone activity (60) and is upregulated by the $\sigma E$ system in response to envelope stress (61). Structuraly, FkpA is a V-shaped homodimer comprised of two monomers, each containing a C-terminal domain with PPIase activity and an N-terminal dimerization domain constituted by three $\alpha$-helices that accommodate the chaperone activity (62). The activity of FkpA as a periplasmic chaperone was initially demonstrated using heterologous proteins expressed in E. coli. Although there is limited data regarding the natural substrates of this folding factor, FkpA was shown to bind unfolded EspP passenger domain with high affinity (63), and recently it has been proposed that this chaperone plays a role in the folding of LptD and FhuA $(59,63)$. 
The periplasmic disulfide bond catalysts DsbA and DsbC that carry out disulfide bond formation and isomerization have been shown to improve both the speed of otherwise slow steps in protein folding and the stability of proteins. DsbA is a monomeric protein with a thioredoxin fold and has a CXXC catalytic motif with a redox-active cysteine pair (Cys30- Cys33) (64). It has been suggested that DsbA is the main oxidant in the periplasm having more than 300 in vivo substrates in $E$. coli (65), including Imp (66), OmpA (67), or the passenger domains of intimin (27) and IcsA (68). DsbA also forms disulfide bonds in LptD, the OMP translocon of LPS (69). It has been shown that DsbA introduces disulfide bonds nonspecifically between consecutive cysteines into proteins entering the periplasm (70), without regard for the correct disulfide pairing that is found in the native conformation. The isomerization of incorrect disulfide bonds is catalyzed by the disulphide isomerase DsbC (71). DsbC is a V-shaped homodimeric protein, and each monomer consists of two domains: an N-terminal dimerization domain and a C-terminal thioredoxin-like domain with a CXXC motif bearing with a redox-active cysteine pair (Cys98-Cys101) (72), which should be maintained in its reduced state for proper isomerase activity in a process mediated by the disulfide reductase DsbD (73). Currently, it is becoming apparent the importance of Dsb systems for bacterial pathogenesis, and numerous Gram-negative pathogens either encode several copies of their Dsb genes or posses functional Dsb paralogs (74). The study of $d s b$ mutants of various bacterial pathogens has shown an impaired assembly of different adhesive organelles (18) and attenuation $(75,76)$, revealing the implication of Dsbs in bacterial virulence and, importantly, that disulfide formation systems are interesting targets for the design of new antimicrobial drugs.

Overall, a possible picture for OMP biogenesis is that major OMPs and certain ATs and LptD may recruit Skp and/or FkpA at an early stage for preventing aggregation. SurA plays a role for targeting the OMP $\beta$-domain and the AT passenger domain of EspP to the BAM complex $(3,40,57,77)$. Although the function of FkpA is still unclear, it has been reported that this protein assists Skp in the folding of certain OMPs (59). FkpA may be a novel quality control factor under heat-shock conditions (78). DsbA and DsbC catalyze the formation of disulfide bonds in cysteine-containing polypeptides. The role of DegP as a chaperone still remains to be elucidated but it clearly plays an important role as a protease in the quality control of OMP biogenesis. In general, translocation incompetent OMPs are degraded by DegP, relieving the cell from the toxic effects associated with the presence of misfolded polypeptides.

Despite the recent advances and the intense research in OMP biogenesis, we still have a relatively poor understanding of how OMPs and ATs, as structural challenging substrates, are maintained in a translocation competent state and transported across the periplasm by the different folding factors. Also, defining the exact role of the different players and how they interact and regulated are important questions that remain unanswered. It is becoming apparent that even homologous chaperones in different species function quite differently. Hence, further studies are thus required to allow an in-depth understanding of the molecular mechanisms that govern the periplasmic transit and assembly of OMPs. 
Section I. Genetic strategy for analyzing the role of periplasmic folding factors

\section{Obtention of conditional depletion mutants of periplasmic folding factors in $E$. coli}

The evidences for the functional role of periplasmic chaperones have been defined in vivo using genetically modified strains bearing either null mutations, or in conditional depletion strains, in which the expression of the chaperone gene can be regulated allowing control of protein levels $(28,55)$.

The procedure presented here describes the generation of a conditional mutant strain in which an inducible araC- $\mathrm{P}_{\mathrm{BAD}}$ promoter cassette replaces the native promoter of surA on the chromosome (Figure 1). The transcriptional activity of the $\mathrm{P}_{\mathrm{BAD}}:$ :surA allele can be controlled by the presence in the growth medium of the inducer L-arabinose or the repressor D-glucose. This strategy was used to obtain conditional mutants in $\operatorname{sur} A(27,33)$ and $\operatorname{bam} A(27)$. This approach can be easily adapted to the periplasmic folding factor of interest in each case.

In this approach we adapted a method developed by the laboratory of Dr JeanMarc Ghigo that combines the lambda-red linear DNA recombination method with site-directed insertion of a repression and expression (RExBAD) cassette that replaces a native promoter with a functional pBAD promoter (79). The mutant strains described here were obtained by one-step inactivation of chromosomal genes with PCR products in E. coli cells bearing the bacteriophage lambda-red recombination system $(80,81)$.

To avoid recombination in the araC gene we generated an E. coli UT5600 knockout strain devoid of araC termed UT5601. Subsequently, this strain was used for generating the RExBAD conditional mutant with regulated surA expression termed $\mathrm{UTP}_{\mathrm{BAD}}:$ :SUrA.

\section{Materials}

\subsection{Bacterial culture}

1. Incubators and shakers set at $30^{\circ} \mathrm{C}, 37^{\circ} \mathrm{C}$ or $42^{\circ} \mathrm{C}$.

2. Spectrophotometer and cuvettes for measuring optical densities of bacterial cultures.

3. LB medium: $10 \mathrm{~g}$ tryptone, $5 \mathrm{~g}$ yeast extract and $10 \mathrm{~g} \mathrm{NaCl}$. Low salt LB medium: $10 \mathrm{~g}$ tryptone, $5 \mathrm{~g}$ yeast extract and $5 \mathrm{~g} \mathrm{NaCl}$. Combine the dry reagents above and add distilled water to $950 \mathrm{ml}$. Adjust pH to 7.5 with $1 \mathrm{~N} \mathrm{NaOH}$ and bring the volume up to 1 liter. SOC medium: Add the following to $900 \mathrm{ml}$ of distilled $\mathrm{H}_{2} \mathrm{O}, 20 \mathrm{~g}$ Tryptone, $5 \mathrm{~g}$ Yeast Extract, $2 \mathrm{ml}$ of $5 \mathrm{M} \mathrm{NaCl}, 2.5 \mathrm{ml}$ of $1 \mathrm{M} \mathrm{KCl}, 10 \mathrm{ml}$ of $1 \mathrm{M} \mathrm{MgCl}_{2}$, $10 \mathrm{ml}$ of $1 \mathrm{M} \mathrm{MgSO}_{4}$. Adjust to $1 \mathrm{~L}$ with distilled $\mathrm{H}_{2} \mathrm{O}$. BHI broth medium: $37 \mathrm{~g}$ of powder with 1 liter of distilled water. Autoclave on liquid cycle at 15 psi and $121^{\circ} \mathrm{C}$ for $20 \mathrm{~min}$ and store at room temperature. For LB agar plates, add $15 \mathrm{~g}$ agar to 1 liter of LB, autoclave as above and allow it to cool at room temperature for at least $55^{\circ} \mathrm{C}$. Add antibiotics as needed, and pour into $100 \mathrm{~mm} \times 15 \mathrm{~mm}$ petri plates using 25-30 ml per plate. 
4. Ampicillin (sodium salt). Dissolve $1 \mathrm{~g}$ of sodium ampicillin in distilled deionized water to a final volume of $10 \mathrm{ml}$. Filter-sterilize the ampicillin solution through a $0,22 \mu \mathrm{m}$ filter. Store the ampicillin in aliquots at $-20^{\circ} \mathrm{C}$ (or at $4^{\circ} \mathrm{C}$ for 3 months).

5. Kanamycin (monosulfate). Make kanamycin to a final concentration of $50 \mathrm{mg} / \mathrm{ml}$ in distilled deionized water. Filter-sterilize as above and store in aliquots at $-20^{\circ} \mathrm{C}$.

6. Zeocin. The stock solution is dissolved at $100 \mathrm{mg} / \mathrm{ml}$ in distilled deionized water. Filter-sterilize as above and store in aliquots at $-20^{\circ} \mathrm{C}$. Do not store at $4^{\circ} \mathrm{C}$ for more than a week. (See Note 1).

7. $20 \% \mathrm{~L}$-Arabinose stock. Dissolve $10 \mathrm{~g}$ in $50 \mathrm{ml}$ of distilled deionized water and filter sterilize.

8. $20 \%$ D-Glucose stock. Dissolve $10 \mathrm{~g}$ in $50 \mathrm{ml}$ of distilled deionized water and filter sterilize.

9. TG1zeoRExBAD E. coli bacterial strain is a gift of Dr. Jean-Marc Ghigo. The zeoRExBAD (zeoR araC PBAD) promoter cassette is a modification of the catRExBAD cassette (79).

10. UT5600 E. coli bacterial strain (82).

11. pKD4 plasmid: Template for gene disruption. OriR6Kgamma, (AmpR, KmR), rgnB(Ter). The Km resistance gene is flanked by FRT sites. Gene Bank: AY048743 (81).

12. pKD46 plasmid: Lambda Red recombinase expression plasmid. repA101(ts), araBp-gam-bet-exo, oriR101, (AmpR). Gene Bank: AY048746 (81).

13. pCP20 plasmid: Has the yeast Flp recombinase gene, ts-rep, [cl857](lambda)(ts), (AmpR, CmR) (83).

\subsection{Recombineering reagents}

1. Thermocycler (e.g., T100 Thermal Cycler, BioRad).

2. Biorad MicroPulser Electroporator (\#165-2100).

3. Electroporation cuvettes - sterile, $0.2 \mathrm{~cm}$ gap, package of 50 (Bio-Rad, 1652086).

4. Agarose. Use at $0.75-1.5 \%$ for analysis of PCR products.

5. Vent DNA polymerase (NEB, M0254S). Enzyme used for generating PCR recombineering substrates.

6. Taq DNA polymerase. Enzyme used for colony PCR.

7. DpnI enzyme (NEB, R0176S). Restriction enzyme used to cleave methylated DNA.

8. QIAprep Spin Miniprep kit (Qiagen). Used for the isolation of plasmids. 
9. QIAquick PCR purification kit (Qiagen) and Qiaex II gel extraction kit (Qiagen). Used for the purification of PCR products to be used as substrates for recombineering.

10. Elution buffer: $10 \mathrm{mM}$ Tris-HCl, pH 8.5.

11. dNTPs: 2.5 mM each of dATP, dCTP, dGTP, dTTP.

12. Sterile distilled water and sterile distilled deionized water.

13. Glycerol.

14. Electroporation washing buffer: Dilute $50 \mathrm{ml}$ of glycerol in $450 \mathrm{ml}$ distilled deionized water and sterilize using $0,22 \mu \mathrm{m}$ filters. Store at $4^{\circ} \mathrm{C}$.

\subsection{Denaturing SDS-PAGE}

1. Electrophoresis system: Bio-Rad Mini-PROTEAN 3 or equivalent. Electrophoresis power supply (PowerPac Basic Power Supply. Bio-Rad, 1645050EDU) or equivalent.

2. Running gel buffer (1 M Tris- $\mathrm{HCl}, \mathrm{pH}$ 8.8): Dissolve $90.9 \mathrm{~g}$ Tris-base in $1 \mathrm{~L}$ of $\mathrm{dH}_{2} \mathrm{O}$, adjust to $\mathrm{pH} 8.8$ with $\mathrm{HCl}$.

3. Stacking gel buffer (1 M Tris- $\mathrm{HCl}, \mathrm{pH}$ 6.8): Dissolve $30.3 \mathrm{~g}$ Tris-base in $1 \mathrm{~L}$ of $\mathrm{dH}_{2} \mathrm{O}$, adjust to $\mathrm{pH} 6.8$ with $\mathrm{HCl}$.

4. 30\% Acrylamide solution: $29.2 \%$ acrylamide/0.8\% bis-acrylamide (See Note 2).

5. Ammonium persulfate (APS) 25\%. Dissolve $2.5 \mathrm{~g}$ APS in a total volume of $10 \mathrm{ml}$ of distilled water. Filter $(0.45 \mu \mathrm{m})$ and make $1-\mathrm{ml}$ aliquots. Store a working aliquot at $4^{\circ} \mathrm{C}$ and the rest of the aliquots at $-80^{\circ} \mathrm{C}$.

6. $10 \%$ SDS. Dissolve $10 \mathrm{~g}$ of SDS in $80 \mathrm{ml}$ of distilled water, and then add distilled water to $100 \mathrm{ml}$. This stock solution is stable for 6 months at room temperature. Caution: Wear a dust mask for protection against breathing SDS powder.

7. Tetramethylethylenediamine (TEMED).

8. 5X Running buffer: 5X Electrophoresis buffer: $15.1 \mathrm{~g}$ Tris base, $72 \mathrm{~g}$ glycine, and $5 \mathrm{~g}$ SDS in 1 liter of distilled water.

9. $2 \times$ sample buffer: Dissolve $2 \mathrm{mg}$ bromophenol blue in $1.25 \mathrm{ml}$ of $1 \mathrm{M}$ Tris- $\mathrm{HCl}$ (pH 6.8), $2 \mathrm{ml}$ of glycerol, $4 \mathrm{ml}$ of $10 \%$ SDS, $0.5 \mathrm{ml}$ of $\beta$-mercaptoethanol (2-ME), and $2.25 \mathrm{ml}$ of $\mathrm{dH}_{2} \mathrm{O}$. Store in aliquots at $-20^{\circ} \mathrm{C}$.

10. Molecular weight marker (e.g., a prestained protein markers, Bio-Rad, or equivalent).

\subsection{Western blotting}

1. Semidry transfer apparatus (e.g., Trans-Blot SD, Bio-Rad, or equivalent).

2. $5 \mathrm{X}$ transfer buffer: $15.1 \mathrm{~g}$ Tris and $72 \mathrm{~g}$ glycine in 1 liter of distilled water. 
3. 1X transfer buffer: Mix $300 \mathrm{ml}$ of $\mathrm{H}_{2} \mathrm{O}, 100 \mathrm{ml}$ of $5 \mathrm{X}$ transfer buffer, $100 \mathrm{ml}$ of methanol, and $1.9 \mathrm{ml}$ of $10 \%$ SDS.

4. PVDF membrane (e.g., Immobilon-P, Millipore).

5. Methanol

6. Extra-thick blot paper (e.g., Bio-Rad); 2-3 mm thickness.

7. Primary antibody: anti-GroEL monoclonal antibody-peroxidase (POD) conjugate $(1: 5,000$; Sigma) and anti-OmpA (1:20,000; a gift of Hiroshi Nikaido), anti-Skp (1:1,000; a gift of Matthias Mueller), anti-MBP-DegP (1:5,000; a gift of Michael Ehrmann), anti-SurA (1:10,000; a gift of Roberto Kolter), anti-Fim D (33).

8. Secondary antibody: bound rabbit antibodies were detected with protein A-POD conjugate (1:8,000; Zymed) (See Note 3).

9. PBS: Dissolve $8 \mathrm{~g} \mathrm{NaCl}, 0.2 \mathrm{~g} \mathrm{KCl}, 1.44 \mathrm{~g} \mathrm{Na}_{2} \mathrm{HPO}_{4}$ and $0.24 \mathrm{~g} \mathrm{KH}_{2} \mathrm{PO}_{4}$ in $800 \mathrm{ml}$ of distilled water. Adjust $\mathrm{pH}$ to 7.4 with $\mathrm{HCl}$; add distilled water to 1 liter and autoclave.

10. PBS-0.1\% Tween 20 (PBST): Mix on magnetic stirrer $1 \mathrm{ml}$ Tween 20 (Sigma, P1379) in 1 liter of PBS.

11. Blocking and antibody dilution solution: dissolve $5 \mathrm{~g}$ of non-fat dry milk in $\mathbf{1 0 0}$ $\mathrm{ml}$ of PBST.

12. X-ray film.

\section{Methods}

\subsection{Obtention of UT5600 $\Delta$ araC (UT5601) E. coli strain}

1. The targeting substrate for recombineering is a PCR product consisting in a Kanamycin (Km) drug marker flanked by upstream and downstream regions of araC target site amplified from pKD4 plasmid template. The primers for the PCR are shown below. The 20 bases on the 3 'end of each oligonucleotide (lower case) anneal to and amplify the $\mathrm{Km}$ cassette, the rest of the bases on the 5 end of each primer (upper case) contain the upstream sequence and the reverse complement of the downstream sequence.

AraC K01 (5'- CCC TAT GCT ACT CCG TCA AGC CGT CAA TTG TCT GAT TCG TTA Cgt gta ggc tgg agc tgc ttc) and AraC KO2 (5'- CCG CCA AAG CTC GCA CAG AAT CAC TGC CAA AAT CGA GGC Cat atg aat atc ctc ctt agt) were used as primers for PCR on pKD4 template.

2. Prepare a PCR reaction $(75 \mu \mathrm{l})$ as follows: $60,75 \mu \mathrm{l}$ sterile deionized water, $7,5 \mu \mathrm{l}$ $10 \times$ Vent PCR buffer (NEB), 1,5 $\mu \mathrm{l}$ dNTPs (10 mM), 1,5 $\mu \mathrm{l}$ primer AraC K01 (20 $\mu \mathrm{M}), 1,5 \mu \mathrm{l}$ primer AraC KO2 $(20 \mu \mathrm{M}), 1,5 \mu \mathrm{l}$ pKD4 (10 ng) and 0,75 $\mu \mathrm{l}$ Vent polymerase (NEB) used as a high fidelity polymerase.

3. Perform standard PCR as follows: (step 1) $95^{\circ} \mathrm{C}, 4 \mathrm{~min}$; (step 2) $94^{\circ} \mathrm{C}, 30 \mathrm{~s}$; (step 3) $59^{\circ} \mathrm{C}, 30 \mathrm{~s}$; (step 4$) 74^{\circ} \mathrm{C}, 2 \mathrm{~min}$. Repeat last three steps 29 times; (step 5) $74^{\circ} \mathrm{C}$, 
$5 \mathrm{~min}$; (step 6) hold at $4^{\circ} \mathrm{C}$. The extension times should be increased for products expected to be longer than $1 \mathrm{~kb}$. When completed, load $10 \mu \mathrm{l}$ of the PCR on a 1\% agarose gel to check for correct size and purity of the PCR product. Clean the PCR product with QIAquick PCR purification kit (Qiagen) and elute DNA in $50 \mu \mathrm{l}$ of elution buffer.

4. Degrade chromosomal DNA that may be present in the sample with DpnI (NEB), a methylation-dependent restriction enzyme that cleaves $\mathrm{Gm} 6 \mathrm{~A}^{\wedge} \mathrm{TC}$ sites. Mix 43 $\mu \mathrm{l}$ of the PCR product with $1 \mu \mathrm{l}$ of DpnI (NEB) and $5 \mu \mathrm{l}$ of 10X CutSmart Buffer (NEB) and incubate at $37^{\circ} \mathrm{C}$ for two hours.

5. Gel-purify the PCR product using a gel extraction kit (Qiaex II, Qiagen) following manufacturer's instructions and elute in $50 \mu \mathrm{l}$ of sterile deionized water.

6. Transform UT5600 E. coli bacterial strain (82) with Red-recombineering plasmid pKD46 (AmpR) following a protocol suited for this purpose. Plate transformation at $30^{\circ} \mathrm{C}$ on $\mathrm{LB}$ plates containing $100 \mu \mathrm{g} / \mathrm{ml} \mathrm{Amp} \mathrm{overnight.}$ Inoculate a fresh colony into $25 \mathrm{ml} \mathrm{LB}$ containing $100 \mu \mathrm{g} / \mathrm{ml} \mathrm{Amp} \mathrm{and} \mathrm{grow}$ overnight at $30^{\circ} \mathrm{C}$.

7. In a $125 \mathrm{ml}$ flask, inoculate $20 \mathrm{ml}$ of LB containing $100 \mu \mathrm{g} / \mathrm{ml}$ ampicillin and $0.2 \%(\mathrm{v} / \mathrm{v}) \mathrm{L}-$ Arabinose with $200 \mu \mathrm{l}$ of the $5 \mathrm{ml}$ overnight (ON) culture containing pKD46. Grow cells shaking $(210 \mathrm{rpm})$ at $30^{\circ} \mathrm{C}$ to an OD of $0.5\left(\sim 10^{8}\right.$ cells $\left./ \mathrm{ml}\right)$.

8. Chill the culture on ice for 5 minutes and pour it into pre-chilled sterile $50 \mathrm{ml}$ Falcon tubes. Collect cells by centrifugation in swinging bucket bench top centrifuge at $3,800 \times \mathrm{g}$ for 20 minutes and $4^{\circ} \mathrm{C}$. Handle tubes gently so as not to disturb the cell pellet. Pour off supernatant slowly, resuspend the cells in $25 \mathrm{ml}$ of ice-cold $10 \%$ glycerol and collect the cells by centrifugation as above. Resuspend the cell pellet in $5 \mathrm{ml}$ of ice-cold 10\% glycerol and centrifuge. Resuspend the cells in $100 \mu \mathrm{l}$ of ice-cold $10 \%$ glycerol by gently pipeting back and forth. Make sure no clumps are present. Place cells on ice and use within $30 \mathrm{~min}$. This amount of cells is good for two to three trials using $50 \mu \mathrm{l}$ of electrocompetent cells per electroporation.

9. Prechill the electroporation cuvettes $(0.2 \mathrm{~cm}$, Bio-Rad) in ice for $10 \mathrm{~min}$. In a prechilled sterile Eppendorf tube, mix $50 \mu \mathrm{l}$ of electrocompetent cells with $3 \mu \mathrm{l}$ of DNA containing 0.1 to 0.5 ng of PCR product. Do not exceed this volume of DNAcontaining sample since it will cause arcing during electroporation.

10. In a Micropulser electroporation apparatus (Bio-Rad) select EC2, a preset protocol for transformation of $E$. coli cells using $0.2 \mathrm{~cm}$ cuvette.

11. Transfer the DNA-bacteria mixture to a prechilled cuvette and incubate on ice for 1 min. Quickly dry the cuvette with kimwipes, place the cuvette into the electroporation chamber, and release charge. Immediately add $1 \mathrm{ml}$ of SOC medium to the cuvette. Pipet back and forth a few times and transfer cells to a 15 $\mathrm{ml}$ sterile Falcon tube or similar. Add another ml of SOC medium to the cuvette and repeat the process. 
12. Grow the $2 \mathrm{ml}$ bacterial culture for 120 min shaking at $30^{\circ} \mathrm{C}$. This step allows phenotypic expression of the resistance marker gene prior to exposure to $\mathrm{Km}$ selection. Spread $0.2 \mathrm{ml}$ aliquots of the culture on LB Amp (100 $\mu \mathrm{g} / \mathrm{ml}) \mathrm{Km}(25$ $\mu \mathrm{g} / \mathrm{ml}$ ) plates and incubate at $30^{\circ} \mathrm{C}$ overnight. Alternatively, the pKD 46 plasmid could be cured by growing the cells on $\mathrm{Km}(25 \mu \mathrm{g} / \mathrm{ml})$ plates at $37^{\circ} \mathrm{C}$ overnight.

13. Screening of recombinants: Restreak candidate $A r a C$ gene knockout colonies on LB Amp (100 $\mu \mathrm{g} / \mathrm{ml}) \mathrm{Km}(25 \mu \mathrm{g} / \mathrm{ml})$ plates and incubate at $30^{\circ} \mathrm{C}$ overnight.

14. Colony PCR can be used to verify the structure of the recombinant. Use a standard Taq polymerase and a primer located upstream or downstream of the sequences used for targeting the gene replacement: AraC2 (5'- CTG GTG GCG ATC TCT TCA CCG GTA GC), and a primer annealing to the drug marker cassette: k2 (5'CGG TGC CCT GAA TGA ACT GC). Perform standard PCR as follows: (step 1) $95^{\circ} \mathrm{C}, 4$ min; (step 2) $94^{\circ} \mathrm{C}, 30 \mathrm{~s}$; (step 3) $55^{\circ} \mathrm{C}, 1 \mathrm{~min}$; (step 4) $72^{\circ} \mathrm{C}, 90 \mathrm{~s}$. Repeat last three steps 29 times; (step 5) $72^{\circ} \mathrm{C}, 10 \mathrm{~min}$; (step 6) hold at $4^{\circ} \mathrm{C}$. When completed, load $10 \mu \mathrm{l}$ of the PCR on a $1 \%$ agarose gel.

\subsection{Obtention of UTP $\mathrm{BAD}_{\mathrm{B}}:$ surA E coli strain}

1. The zeoRExBAD (zeoR araC-P $\mathrm{BAD}_{\mathrm{BA}}$ ) cassette was amplified from the chromosome of $E$. coli strain TG1zeoRExBAD using specific oligonucleotide primers hybridizing with the upstream promoter region of the surA gene ( $5^{\prime}$ primer) and the beginning of their coding sequences (3' primer), named ZEOBAD surA1 (5'-CGC AAG AGA TGC TGC GTT CGA ACA TTC TGC CGT ATC AAA ACA CTT TGT GAa gca atg ctt gca taa tgt gcc tgt c-3') and ZEOBAD surA2 (5'-CTG GTA TTC GCG ATC ATG GCG ATA CCG AGA AGC AGC GTT TTC CAG TTC TTC CAT cgt ttc act cca tcc aaa aaa acg ggt-3'). The uppercase letters correspond to the sequence hybridizing to surA upstream or coding sequences. The lowercase letters correspond to the sequence hybridizing to the zeoRExBAD cassette. In bold is the first codon of surA coding sequence. Use standard PCR conditions, as described above. The PCR fragment with zeoR araC$\mathrm{P}_{\mathrm{BAD}}$ cassette is approximately $1.9 \mathrm{~kb}$.

2. Clean the PCR product with QIAquick PCR purification kit (Qiagen) and elute DNA in $50 \mu \mathrm{l}$ of elution buffer. Digest chromosomal DNA with DpnI (NEB). Mix 43 $\mu \mathrm{l}$ of the PCR product with $1 \mu \mathrm{l}$ of DpnI (NEB) and $5 \mu \mathrm{l}$ of NEB buffer 4 (10X) and incubate at $37^{\circ} \mathrm{C}$ for two hours. Gel-purify the PCR product using the Qiaex II gel extraction kit and elute in $50 \mu \mathrm{l}$ of sterile deionized water.

3. Preparation of electrocompetent UT5601 E. coli cells carrying pKD46: Inoculate a fresh colony of UT5601 E. coli cells carrying pKD46 into $25 \mathrm{ml}$ LB containing Amp $(100 \mu \mathrm{g} / \mathrm{ml})$ and $\mathrm{Km}(25 \mu \mathrm{g} / \mathrm{ml})$. Grow overnight shaking at $30^{\circ} \mathrm{C}$.

4. In a $125 \mathrm{ml}$ flask, inoculate $20 \mathrm{ml}$ of LB containing Amp (100 $\mu \mathrm{g} / \mathrm{ml}), \mathrm{Km}(25$ $\mu \mathrm{g} / \mathrm{ml}$ ) and $0.2 \%(\mathrm{v} / \mathrm{v})$ L-Arabinose with $200 \mu \mathrm{l}$ of a $5 \mathrm{ml}$ overnight culture. Grow cells shaking $(210 \mathrm{rpm})$ at $30^{\circ} \mathrm{C}$ to an OD of $0.5\left(\sim 10^{8}\right.$ cells $\left./ \mathrm{ml}\right)$.

5. Proceed as described in sections 8 to 11 from subheading 3.1.

6. After electroporation, grow $2 \mathrm{ml}$ of the bacterial culture for $120 \mathrm{~min}$ shaking at $30^{\circ} \mathrm{C}$. Spread $0.2 \mathrm{ml}$ aliquots of the culture on low salt LB medium containing $0.2 \%$ 
$(\mathrm{v} / \mathrm{v})$ arabinose and Zeo $(40 \mu \mathrm{g} / \mathrm{ml})$. The presence of L-arabinose is required for surA expression in putative UTP $\mathrm{BAD}_{\mathrm{BD}}:$ surA cells. Incubate at $37^{\circ} \mathrm{C}$ overnight to remove pKD46 plasmid.

7. Screening of recombinants: Restreak candidate UTP $\mathrm{BAD}_{\mathrm{BD}}:$ surA colonies on low salt LB Zeo $(40 \mu \mathrm{g} / \mathrm{ml})$ plates containing $0.2 \%(\mathrm{v} / \mathrm{v})$ arabinose and incubate at $30^{\circ} \mathrm{C}$ overnight.

8. The insertion of the zeoRExBAD cassette in the promoter region of surA can be tested by colony PCR with oligonucleotides Zeo1 (5'-CAC TGG TCA ACT TGG CCA TGG TTT AG-3') and SurA2 (5'-CAT TAA TCC ATC AAC GTC GCT TTC CAG CAC-3'). Use standard PCR conditions, as described above. When completed, load $10 \mu \mathrm{l}$ of the PCR on a $1 \%$ agarose gel. (See Note 4 )

Elimination of $\mathrm{Km}$ selection marker: if desired, the $\mathrm{Km}$ selective marker can be removed after transformation with temperature-sensitive helper plasmid pCP20. This FLP expression plasmid is resistant to ampicillin at $30^{\circ} \mathrm{C}(81)$.

9. Grow transformed UTP $\mathrm{BAD}:: s u r A$ bacteria with pCP20 plasmid on LB Amp (100 $\mu \mathrm{g} / \mathrm{ml})$ plates containing $0.2 \%(\mathrm{v} / \mathrm{v})$ arabinose and incubate at $30^{\circ} \mathrm{C}$ overnight. Induce the flipase and plasmid loss by shifting the temperature to $42^{\circ} \mathrm{C}$ and overnight incubation. The resulting integrants are then spread on nonselective LB medium agar at $40^{\circ} \mathrm{C}$ for overnight. Cell colonies appearing on plates are again picked and patched onto LB agar plates containing Amp and $\mathrm{Km}$, respectively. Consequently, the integrants are picked for exhibiting sensitivity to both Amp (indicating loss of the helper plasmid) and $\mathrm{Km}$ (indicating removal of the marker).

\subsection{Functional analysis of SurA depletion}

As mentioned before the expression of SurA in this conditional mutant can be controlled by the presence in the growth medium of the inducer L-arabinose or the repressor D-glucose. The conditional expression of SurA and its impact in the OM folding of the usher protein FimD of type 1 fimbriae are monitored as follows.

1. Inoculate a single colony of UTPBAD::surA in $20 \mathrm{ml}$ of liquid brain heart infusion (BHI) medium containing 0.4\% (w/v) L-arabinose and Kanamycin $(25 \mu \mathrm{g} / \mathrm{ml}$ ) (See Note 5). Grow the culture at $37^{\circ} \mathrm{C}$ under static conditions for 16 hours. Dilute the preinoculum cultures to an $\mathrm{OD}_{600}$ of 0.05 in $10 \mathrm{ml}$ of fresh medium containing either $0.4 \%(\mathrm{w} / \mathrm{v})$ L-arabinose (inducing conditions) or $0.4 \%(\mathrm{w} / \mathrm{v})$ D-glucose (repressing conditions) and Kanamycin $(25 \mu \mathrm{g} / \mathrm{ml})$. Grow the cultures at $37^{\circ} \mathrm{C}$ without shaking for type 1 fimbriae expression (FimD) and after 3 hours dilute them in $10 \mathrm{ml}$ of inducing or depletion medium to an $\mathrm{OD}_{600}$ of 0.05 and grew for an additional 3 hours. Repeat this process one more time. Follow the growth of the bacterial cultures by taking $\mathrm{OD}_{600}$ readings each hour. Before culture dilution (indicated by roman numbers I, II, and III in Figure 2A) remove samples $(0.25$ $\mathrm{OD}_{600}$ units) for western botting.

2. Harvest bacteria by centrifugation $(3,300 \times \mathrm{g}, 3 \mathrm{~min})$ and prepare whole cell extracts as follows. Resuspend the cell pellet in $25 \mu \mathrm{l}$ of PBS and mix it with the same volume of $2 \times$ SDS sample buffer. 
3. Sonicate the samples on ice (5-10 s) with a thin needle at maximum power and spin $(14,000 \mathrm{x} \mathrm{g}, 5 \mathrm{~min})$ to remove insoluble material before loading onto an SDSPAGE gel.

4. Load samples in 12\% SDS-PAGE and perform Western blotting to detect the levels of folded and unfolded FimD, OmpA; the periplasmic chaperones SurA, Skp, and DegP; and cytoplasmic GroEL as an internal loading control. The procedure for SDS-PAGE and Western blotting has been precisely described elsewhere $(84,85)$.

\subsection{Example of results.}

As shown in Figure 2B, the steady-state level of SurA during continuous exponential growth with L-arabinose is clearly sufficient for proper expression and folding of FimD and OmpA. However, depletion of SurA from bacteria grown with D-glucose diminished the levels of FimD. The OmpA expression also decreased in depleting medium, although not as dramatically as FimD, since folded OmpA was clearly detectable when SurA was depleted from bacteria. Since DegP is not significantly upregulated under these conditions, these results indicate that SurA is required for FimD folding and insertion in the OM of E. coli.

\section{Section II. Biochemical assessment of OMP folding}

\section{Mobility shift and protease accessibility assays for OMPs}

Herein, we describe two simple methods traditionally used to evaluate the folding of OMPs, which are based in the compact folding adopted by correctly folded OMPs in the OM that confers distinct biochemical properties.

Usually natively folded OMPs do not denature in SDS sample buffer if not heated before SDS-PAGE, whereas OMPs displaying folding defects are sensitive to SDS. Thus, independently of their oligomeric state, the folding conformation of OMPs can be easily distinguished by analyzing their heat-modifiable property in SDSPAGE $(86,87)$. Correctly folded OMPs acquire a compact SDS-resistant structure that migrates faster in SDS-PAGE gels than the unfolded polypeptides.

Also, OMPs are usually highly resistant to proteases when they are correctly assembled in the $\mathrm{OM}$, being either totally protected against the proteolytic treatment or yielding discrete degradation products, such as the membrane embedded $\beta$-barrel portion of the OMP. This can be assessed in vivo by incubating bacterial cells with proteases such as trypsin or proteinase K. An increased sensitivity to protease treatment is often seen as an indicative of an alteration in the folding of the protein.

As an example, we will show the heat-modifiable mobility of the OMP intimin and its resistance to the treatment with proteinase $\mathrm{K}$.

Intimins are large polypeptides (ca. $95 \mathrm{kDa}$ ) located at the surface of enteropathogenic and enterohemorrhagic E. coli strains (EPEC and EHEC, respectively) (Figure 3A). The $\mathrm{N}$ region of intimins (residues 1 to 550) anchors the protein in the $\mathrm{OM}$ and is highly conserved among intimins from different strains 
( $>95 \%$ identity). This region contains a $\beta$-barrel domain embedded in the OM (88). The extracellular $C$ region of intimins is less conserved (ca. 50 to $70 \%$ identity) and forms a rigid rod that binds to the translocated intimin receptor (Tir) $(89,90)$. This region contains three immunoglobulin-like domains (named D0, D1, and D2) and a C-type lectin like domain (D3) (91). Intimin EPEC $_{\text {contains two Cys residues (Cys-860 }}$ and Cys-937) in domain D3 that form an intra-domain disulfide bond $(92,93)$ catalyzed by DsbA the periplasm (27).

\section{Materials}

\subsection{Bacterial culture}

1. Incubators and shakers

2. Spectrophotometer and cuvettes for measuring optical densities of bacterial cultures.

3. LB medium and LB agar plates as describe above on paragraph 2.1 Bacterial culture of Section I.

4. E. coli UT5600 wild type (82), UT5600dsbA (94) and EPEC E2348/69 strain (95).

5. pCVD438 plasmid expressing intimin ${ }_{\mathrm{EPEC}}($ eae) (96). This plasmid carries the eaeA gene from EPEC under the control of its natural promoter and was previously used for complementation of $\triangle$ eae mutants of EPEC and C. rodentium (97).

6. Chloramphenicol (34 mg/ml). Dissolve $340 \mathrm{mg}$ chloramphenicol stock in $10 \mathrm{ml}$ $(100 \%)$ ethanol. If necessary, vortex solution to ensure the antibiotic is fully dissolved. Filter sterilze this solution using a $0.2 \mu \mathrm{m}$ syringe filter. Aliquot (500 $\mu \mathrm{l}$ $1 \mathrm{ml}$ aliquots are useful) and store at $-20^{\circ} \mathrm{C}$ until use.

8. $\beta$-mercaptoethanol (2-ME).

\subsection{Protease digestion}

1. Sonicator.

2. Proteinase $\mathrm{K}(\mathrm{PK})$ at $10 \mathrm{mg} / \mathrm{ml}$ (Sigma). See Note 6.

3. Phenyl-methylsulfonyl fluoride (PMSF) $100 \mathrm{mM}$. Dissolve $17.4 \mathrm{mg}$ PMSF in $1 \mathrm{ml}$ of ethanol. Caution: Wear gloves as PMSF is highly toxic and carcinogenic.

4. PBS: Dissolve $8 \mathrm{~g} \mathrm{NaCl}, 0.2 \mathrm{~g} \mathrm{KCl}, 1.44 \mathrm{~g} \mathrm{Na}_{2} \mathrm{HPO}_{4}$, and $0.24 \mathrm{~g} \mathrm{KH}_{2} \mathrm{PO}_{4}$ in $800 \mathrm{ml}$ of distilled water. Adjust $\mathrm{pH}$ to 7.4 with $\mathrm{HCl}$; add distilled water to 1 liter and autoclave.

\subsection{Denaturing SDS-PAGE}

Prepare materials as in Subheading 2.3, Section I, with the following modifications

1. Prepare urea-SDS sample buffer $(2 \times)$ for achieving complete denaturation of intimin polypeptides. The urea-SDS sample buffer $(1 \times)$ contains $60 \mathrm{mM}$ Tris-HCl (pH 6.8), 2\% (w/v) SDS, 4 M urea, 5 mM EDTA, 5\% (v/v) glycerol, 0.005\% (w/v) bromophenol blue, and 1\% (v/v) 2-ME. See Note 7. 


\subsection{Western blot}

Prepare materials as in Subheading 2.4, Section I. The antibodies are as follows:

1. Primary antibody: rabbit anti-Int280EPEC polyclonal serum (1:200; a gift from Gad Frankel).

2. Secondary antibody: bound rabbit antibodies were detected with protein A-POD conjugate $(1: 8,000 ;$ Zymed).

\section{Methods}

\subsection{Mobility shift assay and Proteinase $K$ digestion of intimin expressed in EPEC and E. coli K12 bacteria}

1. For expression of intimin in EPEC bacteria, inoculate a fresh colony of EPEC E2348/69 strain (95) in $25 \mathrm{ml} \mathrm{LB}$ medium and grow statically at $37^{\circ} \mathrm{C}$ for $16 \mathrm{~h}$.

2. Dilute the bacterial culture in fresh LB medium to a final optical density at 600 $\mathrm{nm}$ (OD600) of 0.1 and grow under identical conditions for 2 hours in the presence or absence of $10 \mathrm{mM} \mathrm{2-ME}$. The reducing agent 2-ME is included for reducing the disulphide bond (Cys-860 and Cys-937) present in intimin that renders this polypeptide sensitive to $\mathrm{PK}$.

3. Measure the optical density at $600 \mathrm{~nm}$ of both cultures (+/- 2-ME) and centrifuge 0.5 ODs (3,300 $\times \mathrm{g}, 3 \mathrm{~min})$. Resuspend the cell pellet in $1 \mathrm{ml}$ of PBS and harvest the cells by centrifugation $(3,300 \times \mathrm{g}, 3 \mathrm{~min})$.

4. Redisperse the cell pellet in $1 \mathrm{ml}$ of PBS and divide into three aliquots of $330 \mu \mathrm{l}$. Resuspend two aliquots in $25 \mu \mathrm{l}$ of PBS and add the same volume of urea-SDS sample buffer $(2 \times)$. Incubate one of the aliquots at $100^{\circ} \mathrm{C}$ for 30 minutes (boiled sample), and kept the other on ice (unboiled sample).

5. Add $40 \mu \mathrm{g} / \mathrm{ml}$ of PK to the third aliquot on ice (PK treated). Incubate at $37^{\circ} \mathrm{C}$ for 20 minutes. Stop the reaction with $1 \mu \mathrm{l}$ of PMSF (100 mM). Resuspend it in $25 \mu \mathrm{l}$ of PBS and add the same volume of urea-SDS sample buffer $(2 \times)$. Boil it for 30 minutes.

6. Sonicate the samples on ice (5-10 s) with a thin needle at maximum power and spin $(14,000 \mathrm{x} \mathrm{g}, 5 \mathrm{~min})$ to remove insoluble material before loading onto an SDSPAGE gel.

7. Load samples in 8\% SDS-PAGE and perform Western blotting to detect EPEC intimin with anti-Int280EPEC polyclonal serum (raised against the secreted domains D1, D2, and D3). The procedure for SDS-PAGE and western blotting has been precisely described elsewhere (98).

8. For heterologous expression of EPEC intimin in wild type E. coli UT5600 or in the isogenic dsbA mutant, transform UT5600 and UT5600dsbA bacteria with pCVD438 plasmid (CmR) following a protocol suited for this purpose. Plate transformation at $30^{\circ} \mathrm{C}$ on LB plates containing $34 \mu \mathrm{g} / \mathrm{ml} \mathrm{Cm}$ and grow overnight. 
9. Inoculate a fresh colony of UT5600/pCVD438 or UT5600dsbA/pCVD438 bacteria into $25 \mathrm{ml} \mathrm{LB}$ medium containing $\mathrm{Cm}$.

10. Grow overnight shaking ( $160 \mathrm{rpm})$ at $37^{\circ} \mathrm{C}$ for constitutive expression.

11. Dilute the bacterial culture in fresh LB medium to a final optical density at 600 $\mathrm{nm}(\mathrm{OD} 600)$ of 0.1 and grow under identical conditions for 2 hours in the presence or absence of $10 \mathrm{mM} 2$-ME.

\section{Repeat from step 3.}

\subsection{Example of results.}

The intimin band shows a mobility of $\sim 95 \mathrm{kDa}$ in the boiled samples, corresponding to the expected mass of full-length intimin and indicating that the polypeptide was completely denatured after boiling in the SDS-urea buffer (Figure $3 \mathrm{~B}$ and $\mathrm{C}$, lane 2). In those samples kept at $4^{\circ} \mathrm{C}$ intimin showed a faster mobility in SDS-PAGE as expected for a folded $\beta$-barrel protein (Figure $3 \mathrm{~B}$ and $\mathrm{C}$, lane 1 ). Intimin requires boiling in the presence of $4 \mathrm{M}$ urea and 2\% SDS for complete unfolding indicating the formation of a very stable $\beta$-barrel in both EPEC and E. coli $\mathrm{K}-12$.

Intimin also shows high resistance to extracellularly added proteases when expressed in EPEC and E. coli UT5600/pCVD438. Full-length intimin bands did not exhibit any sign of proteolytic digestion after incubation of intact bacteria with PK (Figure $3 \mathrm{~B}$ and $\mathrm{C}$, lane 3 ). Nonetheless, intimin is sensitive to $\mathrm{PK}$ when the reducing agent 2-ME was added to the growth medium of EPEC and E. coli UT5600/pCVD438. Bacteria grown with 2-ME and incubated with PK showed almost the complete digestion of the full-length intimin band and the simultaneous appearance of a $\sim 66-\mathrm{kDa}$ proteolytic product (Figure 3B and $\mathrm{C}$, lane 6 ). The growth of EPEC and E. coli UT5600/pCVD438 bacteria with 2-ME did not affect folding of the $\beta$-barrel of intimin, as demonstrated by its resistance to urea-SDS denaturation and its heat-modifiable mobility (Figure $3 \mathrm{~B}$ and $\mathrm{C}$, lanes 4 and 5). These data indicate that such reducing conditions render intimin accessible in the extracellular medium to the action of the protease, and suggest that the increased sensitivity to PK was caused by alterations elsewhere in the protein.

Intimin shows identical heat-modifiable mobility and resistance to urea-SDS denaturation in wild-type $E$. coli UT5600/pCVD438 bacteria and $d s b A$ mutant UT5600dsbA/pCVD438 bacteria (Figure 4). However, as observed under reducing growth conditions (Figure $3 \mathrm{~B}$ and $\mathrm{C}$ ), intimin produced in $d s b A$ mutant bacteria was sensitive to PK digestion (Figure 4). Therefore, the absence of DsbA makes intimin less stable and susceptible to protease digestion, likely due to the misfolding of the secreted D3 domain that contains the single disulfide bond between Cys-860 and Cys-937. 


\section{Section III. Disulfide bond formation in OMPs}

\section{Analysis of the redox state of cysteine residues in OMPs with alkylating agents}

In this method we determine whether two cysteine residues present in a protein are oxidized by DsbA to form a disulfide bond. This is an important question to address when investigating the molecular mechanisms that take place during the periplasmic transit of OMPs. For instance, DsbA catalyzes the formation of the disulfide bond (Cys-860-Cys-937) present in the D3 lectin-like domain of EPEC intimin, indicating that this secreted C-terminal domain is at least partially folded prior to its translocation across the OM (27).

For this purpose, an alkylation assay is performed with the polyethylene glycol (PEG)-conjugated maleimide (mPEG-MAL, ca. $5000 \mathrm{Da}$ ) or with 4-acetamido-40maleimidylstilbene-2,20- disulfonic acid (AMS, ca. $500 \mathrm{Da}$ ) that covalently binds to free sulfydryl groups in proteins.

Maleimide-activated crosslinkers (mPEG-MAL or AMS) react with the free thiolate groups of reduced cysteine residues $(-\mathrm{SH})$ in proteins at near neutral conditions ( $\mathrm{pH}$ 6.5-7.5) to form covalent thioether linkages increasing their molecular mass and preventing any further oxidation. Hence, disulfide bonds in protein structures (e.g., between cysteines) must be reduced to free thiols to react with such maleimide reagents. In contrast, cysteine residues involved in a disulfide bond are not modified. Thus, oxidized proteins migrate with the expected size in nonreducing SDS-PAGE, whereas reduced proteins are shifted towards higher molecular weights. See Note 8.

\section{Materials}

\subsection{Bacterial culture}

\section{Incubators and shakers}

2. Spectrophotometer and cuvettes for measuring optical densities of bacterial cultures.

3. LB medium: $10 \mathrm{~g}$ tryptone, $5 \mathrm{~g}$ yeast extract, $10 \mathrm{~g} \mathrm{NaCl}$. Combine the dry reagents above and add distilled water to $950 \mathrm{~mL}$. Adjust $\mathrm{pH}$ to 7.5 with $1 \mathrm{~N} \mathrm{NaOH}$ and bring the volume up to 1 liter. Autoclave and store at room temperature.

4. LB agar plates: add $15 \mathrm{~g}$ agar, autoclave as above and allow to cool at room temperature for at least $55^{\circ} \mathrm{C}$. Add antibiotics as needed, and pour into 100 $\mathrm{mm} \times 15 \mathrm{~mm}$ petri plates using $25-30 \mathrm{ml}$ per plate.

5. Three E. coli strains are used in our study: E. coli UT5600 wild type (82), UT5600dsbA (94) and EPEC E2348/69 strain (95).

6. The pCVD438 plasmid expressing intimin ${ }_{\mathrm{EPEC}}(e a e)(96)$.

7. Chloramphenicol. Dissolve $340 \mathrm{mg}$ chloramphenicol stock in $10 \mathrm{~mL}(100 \%)$ ethanol. If necessary, vortex solution to ensure the antibiotic is fully dissolved. 
Filter sterilze solution using a $0.2 \mu \mathrm{m}$ syringe filter. Aliquot ( $500 \mu \mathrm{L}-1 \mathrm{~mL}$ aliquots are useful) and store at $-20^{\circ} \mathrm{C}$ until use.

\subsection{Alkylation assay}

1. $1 \mathrm{M}$ dithiothreitol (DTT): Dissolve $0,15 \mathrm{~g}$ in $1 \mathrm{ml} \mathrm{H}_{2} 0$

2. Alkylation buffer (AK): $80 \mathrm{mM}$ Tris- $\mathrm{HCl}$ [pH 6.8], $150 \mathrm{mM} \mathrm{NaCl}$

3. $10 \mathrm{mM}$ mPEG-MAL: Dissolve $0,05 \mathrm{~g}$ in $0,25 \mathrm{ml} \mathrm{AK}$ buffer. It is prepare on the moment, ready to use because lost fastly the alkylation activity. See Note 9.

4. $100 \%(\mathrm{w} / \mathrm{v}$ ) Trichloroacetic acid (TCA): dissolve 500g TCA (as shipped) into $350 \mathrm{ml} \mathrm{dH} 20$, store at RT.

\section{Acetone}

6. Glycerol

7. PBS: Dissolve $8 \mathrm{~g} \mathrm{NaCl}, 0.2 \mathrm{~g} \mathrm{KCl}, 1.44 \mathrm{~g} \mathrm{Na}_{2} \mathrm{HPO}_{4}$, and $0.24 \mathrm{~g} \mathrm{KH}_{2} \mathrm{PO}_{4}$ in $800 \mathrm{ml}$ of distilled water. Adjust $\mathrm{pH}$ to 7.4 with $\mathrm{HCl}$; add distilled water to 1 liter and autoclave.

\subsection{Non-reducing SDS-PAGE}

Prepare materials as described in Subheading 2.3 of Section I.

1. Prepare non-reducing urea-SDS-sample buffer $(2 \times)$ (without 2-ME) The nonreducing urea-SDS sample buffer (1x) contains $60 \mathrm{mM}$ Tris- $\mathrm{HCl}(\mathrm{pH} 6.8), 2 \%(\mathrm{w} / \mathrm{v})$ SDS, 4 M urea, 5 mM EDTA, 5\% (v/v) glycerol and 0.005\% (w/v) bromophenol blue.

\subsection{Western blotting}

Prepare materials as in Subheading 2.4, Section I. The antibodies are as follows:

1. Primary antibody: rabbit anti-Int280EPEC polyclonal serum (1:200; a gift from Gad Frankel).

2. Secondary antibody: bound rabbit antibodies were detected with protein A-POD conjugate $(1: 8,000 ;$ Zymed).

\section{Methods}

\subsection{Alkylation assay of intimin expressed in EPEC and E. coli K12 bacteria with MPEG-MAL}

1. Transform UT5600 and UT5600dsbA E. coli bacterial strains with pCVD 438 plasmid $(\mathrm{CmR})$ following a protocol suited for this purpose. Plate transformation at $30^{\circ} \mathrm{C}$ on LB plates containing $34 \mu \mathrm{g} / \mathrm{ml} \mathrm{Cm}$ overnight.

2. For expression of intimin in E. coli K-12 strains, inoculate a fresh colony of UT5600 or UT5600dsbA bacteria carrying pCVD438 plasmid into $25 \mathrm{ml}$ LB medium containing $\mathrm{Cm}(34 \mu \mathrm{g} / \mathrm{ml})$. 
3. Grow overnight shaking (160 rpm) at $37^{\circ} \mathrm{C}$ for constitutive expression.

4. For expression of intimin in EPEC bacteria, inoculate a fresh colony of EPEC E2348/69 strain (95) in $25 \mathrm{ml} \mathrm{LB}$ medium and grow statically at $37^{\circ} \mathrm{C}$ for $16 \mathrm{~h}$.

5. Dilute the bacterial culture in fresh LB medium to a final optical density at 600 $\mathrm{nm}$ (OD600) of 0.05 , and grown under identical conditions for additional 4 hours.

6. Harvest UT5600dsbA/pCVD438, UT5600/pCVD438 and EPEC bacteria by centrifugation $(3,300 \times \mathrm{g}, 3 \mathrm{~min})$. Resuspend the cells to an OD600 of 1.0 in $2 \mathrm{ml}$ of PBS and pellet again by centrifugation (3,300 $\times \mathrm{g}, 3 \mathrm{~min})$. Wash twice with $1 \mathrm{ml}$ of PBS by centrifugation $(3,300 \times \mathrm{g}, 3 \mathrm{~min})$.

7. Resuspend the cell pellet in $0.5 \mathrm{ml}$ of buffer $\mathrm{AK}$ and divide the suspension into four aliquots of $100 \mu \mathrm{l}$. Incubate two of them with $100 \mathrm{mM}$ dithiothreitol (DTT) on ice for $10 \mathrm{~min}$ and then incubate at $60^{\circ} \mathrm{C}$ for an additional $10 \mathrm{~min}$ (DTT-treated samples). See Note 10.

8. Wash DTT-treated and untreated samples with $1 \mathrm{ml}$ of PBS two times by centrifugation $(3,300 \times \mathrm{g}, 3 \mathrm{~min})$. Resuspend one sample from each group in $50 \mu \mathrm{l}$ of AK buffer containing 10 mM mPEG-MAL (mPEG-Mal, Mr 5,000; Nektar Therapeutics, San Carlos, CA), and resuspend the remaining samples in $50 \mu \mathrm{AK}$ buffer. Perform the alkylation reaction for 30 minutes at room temperature.

9. Precipitate the proteins with trichloroacetic acid (10\% [wt/vol]) for $1 \mathrm{~h}$ at $4^{\circ} \mathrm{C}$, and recover the precipitates by centrifugation $(14,000 \times \mathrm{g}, 15 \mathrm{~min})$.

10. Wash the protein pellets with $1 \mathrm{ml}$ of ice-cold acetone, followed by centrifugation $(14,000 \times \mathrm{g}, 15 \mathrm{~min})$.

11. Dry pellet by placing tube in $95^{\circ} \mathrm{C}$ heat block for $5-10 \mathrm{~min}$ to drive off acetone and resuspend in $30 \mu \mathrm{l}$ of AK buffer containing 1\% (w/v) SDS and 5\% (v/v) glycerol. Samples were mixed with the same volume of nonreducing urea-SDSsample buffer $(2 \times)$ (without 2-ME) before being loaded onto SDS-PAGE gels.

12. The redox state of intimin is analyzed by standard SDS-PAGE and Western blot protocols as describedd previously. Immunodetection of intimin is performed with rabbit polyclonal anti-intimin-280EPEC antibody (1:200; a gift from Gad Frankel). Bound rabbit antibodies were detected with protein A-POD conjugate $(1: 8,000$; Zymed).

\subsection{Example of results.}

To gain a direct evidence of the formation disulfide bond (Cys-860-Cys-937) by DsbA, the in vivo redox state of intimin was compared in wild-type and dsbA mutant $E$. coli K-12 strains carrying pCVD438. The experiment shows that intimin reacts to mPEG-MAL when expressed in the dsbA mutant, in which a highmolecular-weight band corresponding to alkylated intimin appears (Figure 5, lane 7). In contrast, intimin expressed in wild-type EPEC or UT5600/pCVD438 bacteria was not reactive to the alkylating agent (Figure 5C, lanes 2 and 5) unless the disulfide bond in $\mathrm{D} 3$ was reduced by the incubation of bacteria with the reducing agent DTT (Figure 5C, lane 3). 
Section IV. Analysis of cuaternary structure of OMPs.

\section{Blue-native PAGE (BN-PAGE) and cross-linking with DSP to follow the cuaternary structure of OMPs}

BN-PAGE relies on the solubilization of protein complexes from the membrane with mild non-ionic detergents (99). These detergents also help to prevent disruption of the protein-protein interactions. The protein complexes are negatively charged with Coomassie brilliant blue G-250 facilitating thus their migration towards the anode and separation according to its size. During electrophoresis, protein complexes separation is obtained with high resolution by the decreasing pore size in the polyacrylamide gradient gel. Always the sample is kept on native condition, the polyacrylamide gels are native (without SDS) and the electrophoresis is under native conditions (without SDS and with Coomassie blue G-250). To this aim, the sample is kept on ice during the preparation steps and running gel. This procedure avoids protein degradation as well as loss of the quaternary structure because separation of protein subunits of the complex.

Intimin is reported to form a homodimer when purified (100). N-terminal fragments of intimin (Int550, and construct Neae with the D0 Ig like domain) and full length intimin were tested by BN-PAGE to evaluate their dimeric structure (27) (Figure 6).

To stabilize protein complexes, intact $E$. coli cells can treated by means of chemical cross-linking in vivo with specific agent as dithiobis-succinimidyl propionate (DSP). DSP is a homobifunctional amine-reactive N-hydroxysuccinimide (NHS) ester which has a spacer arm of $12 \AA$ and a disulfide bond that can be cleaved with reducing agents (e.g. 2-ME). Reducing agents allow identification of the individual components within an oligomeric complex. The advantage of this technique is that it can do it with intact cells without any treatment or purification. The concentration of crosslinker, as well as the length and temperature of the crosslinking reaction, are critical parameters and should not be varied. Few crosslinking results in a ladder of partially crosslinked products whereas over crosslinking can produce a wrong conclusion because on non-specific crossreaction that do not reflect true interactions.

C-terminal $\beta$-domain of ATs were used as a model to test quaternary structure into the OM. Each construct for of the C-terminal domain are tagged with an epitope (Etag) to allow the detection with specific mAb antibody in a Western blot. After induction of these constructs with IPTG, cell cultures were incubated with DSP and bacterial suspensions were mixed with either reducing or nonreducing SDS-PAGE sample buffer, boiled and subjected to Western blotting with anti-E tab mAb-POD (101) (Figure 7).

\section{Materials}

\subsection{Bacterial culture}

1. Incubators and shakers 
2. Spectrophotometer and cuvettes for measuring optical densities of bacterial cultures.

3. LB medium and LB agar plates as describe above on paragraph 2.1 Bacterial culture of Section I.

4. E. coli UT5600 wild type (82) and EPEC E2348/69 (95).

5. pInt550 and pNeae plasmids expressing intimin ${ }_{E P E C}(\mathrm{eae})$ polypeptides (27). ATs plasmids with C-terminal domain fused to 6xHistidine-tag and E-tag (101). All the plasmid are CmR and derivated from pAK-Not (82).

6. Chloramphenicol $(\mathrm{Cm})$ as previously describe.

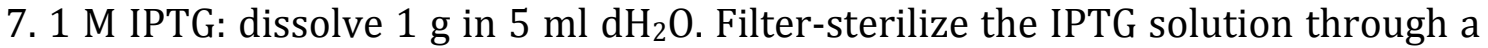
$0,22 \mu \mathrm{m}$ filter. Store the IPTG in aliquots at $-20^{\circ} \mathrm{C}$ and one aliquot ready to use at $4^{\circ} \mathrm{C}$.

\subsection{BN-PAGE}

1. Electrophoresis system: Bio-Rad Mini-PROTEAN 3 or equivalent.

2. Electrophoresis power supply (PowerPac Basic Power Supply. Bio-Rad, 164$5050 \mathrm{EDU}$ ) or power supply capable of providing constant voltage of $150 \mathrm{~V}$ or higher.

3. Electrophoresis buffer: $50 \mathrm{mM}$ Bis-Tris-HCl, $500 \mathrm{mM} \mathrm{6-aminocaproic} \mathrm{acid,} \mathrm{10 \%}$ (v/v) glycerol pH 7.0.

4. The cathode buffer consisted of $50 \mathrm{mM}$ Tricine, $15 \mathrm{mM}$ Bis-Tris- $\mathrm{HCl} \mathrm{pH} 7.0$ and $0.002 \%(\mathrm{w} / \mathrm{v}$ ) Coomassie blue G250.

5. The anode buffer contained $50 \mathrm{mM}$ Bis-Tris-HCl pH 7.0.

6. Protein standards of high molecular mass (66 to $669 \mathrm{kDa}$ ) for native electrophoresis (commercial) were resuspended at a $2.5 \mathrm{mg} / \mathrm{ml}$ final concentration in $50 \mathrm{mM}$ Bis-Tris- $\mathrm{HCl}$ pH 7.0 containing $750 \mathrm{mM}$ 6-aminocaproic acid.

7. Sample buffer: $20 \mathrm{mM}$ Tris-HCl pH 8.0, $10 \mathrm{mM} \mathrm{NaCl}, 1 \%$ (w/v) Zwittergent 3-14, $8.7 \%(\mathrm{v} / \mathrm{v})$ glycerol and $0.5 \%(\mathrm{w} / \mathrm{v})$ Coomassie blue G-250.

Stocks solution: 10\% (w/v) Zwittergent 3-14, 87\% (v/v) glycerol and 5\% (w/v) Coomassie blue G-250.

8. To prepare the separating (polyacrylamide gradient gel) and stacking gel is necessary the following solutions:

- AB solution: $49.5 \% \mathrm{~T}$ and $3 \% \mathrm{C}$

$\% \mathrm{~T}$, total concentration of both monomers acrylamide and bis-acrylamide.

$\% \mathrm{C}$, percentage of cross-linker relative to the total concentration.

- Buffer 3x: 150mM Bistris/HCl pH 7.0, 1.5 M 6-aminocaproic acid 
- Glycerol 87\% (v/v)

- $10 \%(\mathrm{w} / \mathrm{v})$ ammonium persulfate (APS) solution. Store at $-20^{\circ} \mathrm{C}$ for long time and at $4^{\circ} \mathrm{C}$ for up to 2 weeks.

- N,N,N,N'-tetramethyl-ethylenediamine (TEMED)

\subsection{Cross-linking with DSP}

1. PBS: Dissolve $8 \mathrm{~g} \mathrm{NaCl}, 0.2 \mathrm{~g} \mathrm{KCl}, 1.44 \mathrm{~g} \mathrm{Na}_{2} \mathrm{HPO}_{4}$ and $0.24 \mathrm{~g} \mathrm{KH}_{2} \mathrm{PO}_{4}$ in $800 \mathrm{ml}$ of distilled water. Adjust $\mathrm{pH}$ to 7.4 with $\mathrm{HCl}$; add distilled water to 1 liter and autoclave.

2. Buffer $1 \mathrm{M}$ Tris-HCl pH 7.5 to quenched crosslinking reaction.

3. DSP (dithio-bis[succinimidyl propionate]) crosslinker must be dissolved in an organic solvent, such as DMSO, and then added to an aqueous crosslinking reaction. Stock solution was prepared at $250 \mathrm{mM}$ on DMSO by rigorous vortexmixing plus $1 \mathrm{~min}$ incubation at $37^{\circ} \mathrm{C}$. A few particles may remain still insoluble.

\subsection{Denaturing SDS-PAGE and Western blotting}

As previously describe on Materials Section I.

1. Primary antibody: E-tag mAb-POD conjugate (1:2,000; GE Bioscience) and rabbit

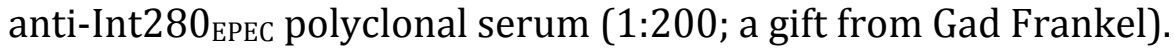

2. Secondary antibody: bound rabbit antibodies were detected with protein A-POD conjugate $(1: 8,000 ;$ Zymed).

\section{Methods}

\subsection{BN-PAGE of outer membrane extract}

1. Prepare polyacrylamide gradiente gels between $4-20 \%$ with a gradient forming and based on (99). This set up allows the separation of protein complexes in the molecular mass range from $\sim 50 \mathrm{kDa}$ to $700 \mathrm{kDa}$.

Prepare separately the higher (20\%) and lower (4\%) percentage of acrylamide, the same volume. Lower percentage of separating gel ( $4 \%$ acrylamide) and stacking gel ( $4 \%$ acrylamide) are prepared equal: $242 \mu \mathrm{l}$ AB solution, $1 \mathrm{ml}$ buffer $3 \mathrm{x}, 25 \mu \mathrm{l}$ APS, $2.5 \mu \mathrm{l}$ TEMED and $1730 \mu \mathrm{l}$ water, without glycerol. The higher percentage of separating gel mix (20\% acrylamide): $1212 \mu \mathrm{l}$ AB solution, $1 \mathrm{ml}$ buffer 3x, $690 \mu$ l glycerol, $15 \mu \mathrm{l}$ APS, $2 \mu \mathrm{l}$ TEMED and $81 \mu \mathrm{l}$ distilled water. Addition of TEMED and APS at the end of the process, just before open valves. Always the higher percentage of acrylamide solution to do the gradient gel must have $20 \%$ of glycerol and put in the position close to the exit in the gradient forming. Place the gradient forming with a magnet rod inside the higher concentration on a magnetic stirrer and connect with the casting stand. Ensure that all ports are closed, between the collectors of acrylamide solutions and with the casting stand. Use soft agitation to avoid air bubbles inside acrylamide solution. Open the two valves at the same time and let the solutions rinse between the glass plates. 
Add distilled water to the top of separating gel during the polymerization process of the gradient gel that should be done around $90 \mathrm{~min}$. Remove distilled water and dry the area above the separating gel completely with thick blot paper (e.g. Whatman) and add the stacking gel with 12-well comb.

2. To obtain the sample, pellet the membrane fraction of your cell culture by centrifugation after lysis step (with French Press or sonication). Remove the supernatant containing all soluble or faint associated proteins to the membranes. Solubilize the pellet on $20 \mathrm{mM}$ Tris- $\mathrm{HCl} \mathrm{pH} 8.0,10 \mathrm{mM} \mathrm{NaCl}$ and $1 \%(\mathrm{w} / \mathrm{v}$ ) Zwittergent 3-14 by gentle agitation and kept on ice. Concentrate sample 100x when resuspended membrane pellet with respect the initial volume culture. Sonicate the sample in a cold sonication bath improve the solubilization of the samples and reduce the time to spend on it. It is important to avoid foam formation during solubilization process. In case of foam it can hinder full sample solubilization. Centrifuge during $30 \mathrm{~min}$ at $4^{\circ} \mathrm{C}$ and $100,000 \mathrm{x} \mathrm{g}$ to pellet the unsolubilized material that can affect in a negative way to the subsequent electrophoretic separation of the protein complexes. Before gel loading, $20 \mu \mathrm{l}$ of this OMP extract was mixed with $2.5 \mu \mathrm{l}$ glycerol $87 \%(\mathrm{v} / \mathrm{v})$ and $2.5 \mu \mathrm{l}$ Coomassie blue G-250 5\% (w/v) and kept on ice.

Protein complex solubilization is the most critical step, for this is important select the appropriate detergent in which is going to solubilize and at what concentration. Protein interaction must be stable with the detergent selected.

3. Load 5 to $10 \mu \mathrm{l}$ of OMPs and resuspended protein standards per well, and electrophoresis was run for $45 \mathrm{~min}$ at $100 \mathrm{~V}$ and for ca. $1 \mathrm{~h}$ at $500 \mathrm{~V}$. As soon as the blue Coomassie dye front has reached half of the separating gel, pause the electrophoretic run and remove the blue cathode buffer from the upper buffer chamber. Refilled with colorless blue native cathode buffer and continue the electrophoretic run. The electrophoresis finish when the blue Coomassie dye front line has reached the bottom of the separating gel (See Note 11).

4. Disassemble the buffer chamber unit and the glass plate sandwich too and remove the stacking gel. Remove blue staining of the gel with distilled water. The blue-gel can transferred directly onto a PVDF membrane using a semidry electrophoresis transfer apparatus to check protein complexes with antibodies.

\subsection{Treatment with DSP of intact E. coli cells}

1. $1 \mathrm{ml}$ of a culture of $E$. coli strain selected on late exponential growth phase, OD600 $\mathrm{nm}$ around $1-1.5$, is centrifuge at $3300 \mathrm{xg} 3 \mathrm{~min}$. The pellet is resuspended in $100 \mu \mathrm{l}$ PBS with or without DSP $2.5 \mathrm{mM}$, concentrated the sample 10 times. DSP must be prepared freshly, ready to use.

2. Cross-linking was carried out for $30 \mathrm{~min}$ at room temperature (RT) with occasional vortex-mixing.

3. Crosslinking reaction must be stooped to ovoid undesirable interactions of the oligomeric complex. For this reason, it was added $5 \mu \mathrm{l}$ of $1 \mathrm{M}$ Tris- $\mathrm{HCl} \mathrm{pH} \mathrm{7.5,} \mathrm{to} \mathrm{a}$ final concentration of $50 \mathrm{mM}$. The incubation was done for $15 \mathrm{~min}$ at RT to quench the reaction. 
5. The cells were washed twice with $10 \mathrm{mM}$ Tris- $\mathrm{HCl} \mathrm{pH} 7.5$ and resuspended in the same buffer at the same volume.

6. One volume of SDS-PAGE with or without 2-ME 5\% (vol/vol) was added to the samples, and then they were boiled 10 min before gel loading (See Note 12).

7. After chemical crosslinking monomeric and oligomeric species be immunoprecipitated and/or analyzed by Western blotting using specific antibodies.

\subsection{Example of results.}

The intimin polypeptides run in the BN-PAGE with a mobility corresponding to the expected size of dimers (Figure 6).

With DSP we evaluated the quaternary structure of C-terminal domains of different ATs from Gram-negative bacteria expressed in E. coli (101). DNA fragments encoding the C-terminal domain of the selected ATs, were cloned into the expression vector pAK-Not (82). The plasmids obtained, named pHEA (Cterminal domain of EhaA), pHES (C-terminal domain of ShdA), pHEI (C-terminal domain of IgAP), pHEN (C-terminal domain of NalP) and pHEBA (C-terminal domain of BruA), encode polypeptides containing the $\mathrm{N}$-terminal signal peptide (sp) of PelB, followed by the His tag $(\mathrm{H})$ and $\mathrm{E}$ tag (E) epitopes and their respective $\mathrm{C}$-terminal domains. The expression of these HE-tagged $\mathrm{C}$-terminal domains was induced with IPTG in E. coli K-12 strain UT5600. After incubation with DSP and with either non-reducing (Figure 7A) or reducing SDS-PAGE buffer (Figure 7B) the samples were analyzed by Western blotting and developed with anti-E-tag antibody. Only HES showed oligomeric state with a strong crosslinking band around $98 \mathrm{kDa}$ corresponding to the predicted size for a dimer. On the contrary, the rest of C-terminal domain ATs were weakly cross-linked (HEA and HEBA) or not cross-linked at all (HEI and HEN), suggesting that they mainly form monomers in the OM in vivo.

\section{Notes.}

1. Any E. coli strain that contains the complete Tn5 transposable element (i.e. DH5 $\alpha F^{\prime} I Q$, SURE, SURE2, MC1066) encodes the ble (bleomycin) resistance gene. These strains will confer resistance to Zeocin. Plates containing Zeocin are stable for 1 month when stored at $4^{\circ} \mathrm{C}$.

2. SDS-PAGE on polyacrylamide gels of $8 \%$ for OMPs around $90-100 \mathrm{kDa}$ or $10 \%$ for OMPs around 45-65 kDa.

3. For POD-developing, a chemiluminescence reaction was prepared using a mixture of $1.25 \mathrm{mM}$ luminol (Sigma) and $42 \mu \mathrm{M}$ luciferin (Roche) in $100 \mathrm{mM}$ Tris$\mathrm{HCl}(\mathrm{pH}$ 8.0). Following a rapid rinse in PBS, the membranes were soaked in this mixture and $\mathrm{H}_{2} \mathrm{O}_{2}$ added at $0.0075 \%(\mathrm{v} / \mathrm{v})$. Alternatively enhanced peroxidase chemiluminescence developer (Roche) was employed. In all cases, after a one minute incubation in the dark, the PVDF-membranes were exposed to an X-ray film (X-OMAT, Kodak). 
4. In the chromosome of wild-type $E$. coli, the surA gene is transcribed with downstream genes pdxA, ksgA, apaG and apaH. These genes are involved in functions unrelated to surA (e.g. pyridoxal 5'-phosphate biosynthesis and methylation of $16 \mathrm{~S}$ rRNA). In addition, these genes are transcribed in pdxA- ksgAapaG-apaH and apaG-apaH transcripts due to the presence of promoters upstream pdxA and apaG (http://biocyc.org/ECOLI).

5. The BHI medium is used for optimal production of type 1 fimbriae (102) and for expression of endogenous FimD in E. coli (33). LB medium was also used for depletion studies of BamA and SurA (27).

6. In this protocol we used Proteinase $\mathrm{K}$ as the protease of choice. Other proteases can be used (e.g., trypsin). In brief, induced E. coli cells were washed and resuspended in PBS, trypsin was added externally $(10 \mu \mathrm{g} / \mathrm{ml})$. Samples were incubated for $20 \mathrm{~min}$ at $37^{\circ} \mathrm{C}$ and stopped by adding trypsin inhibitor $(5 \mu \mathrm{g} / \mathrm{ml}$; Sigma). Total protein extracts from these cells can be analyzed by Western blotting.

7. We found that intimin requires boiling in the presence of $4 \mathrm{M}$ urea and $2 \%$ SDS for complete unfolding, indicating the formation of a very stable $\beta$-barrel in both EPEC and E. coli K-12 (27).

8. Extraneous thiols (most reducing agents) must be excluded from maleimide reaction buffers, because they will compete for coupling sites.

9. mPEG-Mal can be substituted with AMS. 4-acetamido-4'-maleimidylstilbene-2,2'disulfonic acid (AMS, Mw $\sim 500 \mathrm{Da}$ ), as described in (103).

10. The DTT treatment is performed as a control in order to determine the mobility of the reduced form of the polypeptide.

\section{Acknowledgement}

GB and EM contribute equally to this work. Work in the laboratory of LAF is supported by research grants from the Spanish "Ministerio de Economía $y$ Competitividad" (MINECO) (BI02011-26689), "Comunidad Autónoma de Madrid" (S2010-BMD-2312), "La Caixa" Foundation, and the European Research Council (ERC-2012-ADG_20120314).

\section{References}

1. Silhavy, T. J., Kahne, D. and Walker, S. (2010) The bacterial cell envelope. Cold Spring Harb Perspect Biol 2, a000414.

2. Hagan, C. L., Silhavy, T. J. and Kahne, D. (2011) beta-Barrel membrane protein assembly by the Bam complex. Annu Rev Biochem 80, 189-210.

3. van Ulsen, P., Rahman, S. U., Jong, W. S., Daleke-Schermerhorn, M. H. and Luirink, J. (2013) Type V secretion: From biogenesis to biotechnology. Biochimica et biophysica acta. 
4. Rigel, N. W. and Silhavy, T. J. (2012) Making a beta-barrel: assembly of outer membrane proteins in Gram-negative bacteria. Current Opinion in Microbiology 15, 189-193.

5. Du Plessis, D. J. F., Nouwen, N. and Driessen, A. J. M. (2011) The Sec translocase. Biochimica Et Biophysica Acta-Biomembranes 1808, 851-865.

6. Wu, T., Malinverni, J., Ruiz, N., Kim, S., Silhavy, T. J. and Kahne, D. (2005) Identification of a multicomponent complex required for outer membrane biogenesis in Escherichia coli. Cell 121, 235-245.

7. Knowles, T. J., Scott-Tucker, A., Overduin, M. and Henderson, I. R. (2009) Membrane protein architects: the role of the BAM complex in outer membrane protein assembly. Nature Reviews Microbiology 7, 206-214.

8. Bardwell, J. C., McGovern, K. and Beckwith, J. (1991) Identification of a protein required for disulfide bond formation in vivo. Cell 67, 581-589.

9. Hayano, T., Takahashi, N., Kato, S., Maki, N. and Suzuki, M. (1991) Two distinct forms of peptidylprolyl-cis-trans-isomerase are expressed separately in periplasmic and cytoplasmic compartments of Escherichia coli cells. Biochemistry 30, 3041-3048.

10. Missiakas, D., Betton, J. M. and Raina, S. (1996) New components of protein folding in extracytoplasmic compartments of Escherichia coli SurA, FkpA and Skp/OmpH. Mol Microbiol 21, 871-884.

11. Lazar, S. W. and Kolter, R. (1996) SurA assists the folding of Escherichia coli outer membrane proteins. Journal of Bacteriology 178, 1770-1773.

12. Chen, R. and Henning, U. (1996) A periplasmic protein (Skp) of Escherichia coli selectively binds a class of outer membrane proteins. Mol Microbiol 19, 12871294.

13. Merdanovic, M., Clausen, T., Kaiser, M., Huber, R. and Ehrmann, M. (2011) Protein Quality Control in the Bacterial Periplasm. Annual Review of Microbiology, Vol 65 65, 149-+.

14. Liechti, G. and Goldberg, J. B. (2012) Outer membrane biogenesis in Escherichia coli, Neisseria meningitidis, and Helicobacter pylori: paradigm deviations in $\mathrm{H}$. pylori. Front Cell Infect Microbiol 2, 29.

15. Geibel, S., Procko, E., Hultgren, S. J., Baker, D. and Waksman, G. (2013) Structural and energetic basis of folded-protein transport by the FimD usher. Nature 496, 243-246.

16. Noinaj, N., Kuszak, A. J., Gumbart, J. C., Lukacik, P., Chang, H. S., Easley, N. C., Lithgow, T. and Buchanan, S. K. (2013) Structural insight into the biogenesis of beta-barrel membrane proteins. Nature 501, 385-+.

17. Goemans, C., Denoncin, K. and Collet, J. F. (2013) Folding mechanisms of periplasmic proteins. Biochimica et biophysica acta.

18. Bodelón, G., Palomino, C. and Fernández, L. A. (2013) Immunoglobulin domains in Escherichia coli and other enterobacteria: from pathogenesis to applications in antibody technologies. FEMS Microbiol Rev 37, 204-250.

19. Geibel, S. and Waksman, G. (2014) The molecular dissection of the chaperoneusher pathway. Biochimica et biophysica acta 1843, 1559-1567.

20. Ruiz, N. and Silhavy, T. J. (2005) Sensing external stress: watchdogs of the Escherichia coli cell envelope. Curr Opin Microbiol 8, 122-126.

21. Bitto, E. and McKay, D. B. (2002) Crystallographic structure of SurA, a molecular chaperone that facilitates folding of outer membrane porins. Structure $10,1489-1498$. 
22. Behrens, S., Maier, R., de Cock, H., Schmid, F. X. and Gross, C. A. (2001) The SurA periplasmic PPlase lacking its parvulin domains functions in vivo and has chaperone activity. Embo Journal 20, 285-294.

23. Xu, X. H., Wang, S. Y., Hu, Y. X. and McKay, D. B. (2007) The periplasmic bacterial molecular chaperone SurA adapts its structure to bind peptides in different conformations to assert a sequence preference for aromatic residues. Journal of Molecular Biology 373, 367-381.

24. Bitto, E. and McKay, D. B. (2003) The periplasmic molecular chaperone protein SurA binds a peptide motif that is characteristic of integral outer membrane proteins. Journal of Biological Chemistry 278, 49316-49322.

25. Ureta, A. R., Endres, R. G., Wingreen, N. S. and Silhavy, T. J. (2007) Kinetic analysis of the assembly of the outer membrane protein LamB in Escherichia coli mutants each lacking a secretion or targeting factor in a different cellular compartment. Journal of Bacteriology 189, 446-454.

26. Ieva, R. and Bernstein, H. D. (2009) Interaction of an autotransporter passenger domain with BamA during its translocation across the bacterial outer membrane. Proceedings of the National Academy of Sciences of the United States of America 106, 19120-19125.

27. Bodelón, G., Marín, E. and Fernández, L. A. (2009) Role of Periplasmic Chaperones and BamA (YaeT/Omp85) in Folding and Secretion of Intimin from Enteropathogenic Escherichia coli Strains. Journal of Bacteriology 191, 5169-5179. 28. Sklar, J. G., Wu, T., Kahne, D. and Silhavy, T. J. (2007) Defining the roles of the periplasmic chaperones SurA, Skp, and DegP in Escherichia coli. Genes \& Development 21, 2473-2484.

29. Bennion, D., Charlson, E. S., Coon, E. and Misra, R. (2010) Dissection of betabarrel outer membrane protein assembly pathways through characterizing BamA POTRA 1 mutants of Escherichia coli. Molecular Microbiology 77, 1153-1171.

30. Heuck, A., Schleiffer, A. and Clausen, T. (2011) Augmenting beta-Augmentation: Structural Basis of How BamB Binds BamA and May Support Folding of Outer Membrane Proteins. Journal of Molecular Biology 406, 659-666.

31. Vertommen, D., Ruiz, N., Leverrier, P., Silhavy, T. J. and Collet, J. F. (2009) Characterization of the role of the Escherichia coli periplasmic chaperone SurA using differential proteomics. Proteomics 9, 2432-2443.

32. Hagan, C. L., Kim, S. and Kahne, D. (2010) Reconstitution of Outer Membrane Protein Assembly from Purified Components. Science (New York, N.Y.) 328, 890892.

33. Palomino, C., Marín, E. and Fernández, L. A. (2011) The Fimbrial Usher FimD Follows the SurA-BamB Pathway for Its Assembly in the Outer Membrane of Escherichia coli. Journal of Bacteriology 193, 5222-5230.

34. Ricci, D. P., Schwalm, J., Gonzales-Cope, M. and Silhavy, T. J. (2013) The Activity and Specificity of the Outer Membrane Protein Chaperone SurA Are Modulated by a Proline Isomerase Domain. Mbio 4.

35. Walton, T. A. and Sousa, M. C. (2004) Crystal structure of Skp, a prefoldin-like chaperone that protects soluble and membrane proteins from aggregation. Molecular Cell 15, 367-374.

36. Qu, J., Mayer, C., Behrens, S., Holst, O. and Kleinschmidt, J. H. (2007) The trimeric periplasmic chaperone skp of Escherichia coli forms $1: 1$ complexes with outer membrane proteins via hydrophobic and electrostatic interactions. Journal of Molecular Biology 374, 91-105. 
37. Burmann, B. M., Wang, C. and Hiller, S. (2013) Conformation and dynamics of the periplasmic membrane-protein-chaperone complexes OmpX-Skp and tOmpASkp. Nat Struct Mol Biol 20, 1265-1272.

38. Schafer, U., Beck, K. and Muller, M. (1999) Skp, a molecular chaperone of gramnegative bacteria, is required for the formation of soluble periplasmic intermediates of outer membrane proteins. Journal of Biological Chemistry 274, 24567-24574.

39. Harms, N., Koningstein, G., Dontje, W., Muller, M., Oudega, B., Luirink, J. and de Cock, H. (2001) The early interaction of the outer membrane protein PhoE with the periplasmic chaperone Skp occurs at the cytoplasmic membrane. Journal of Biological Chemistry 276, 18804-18811.

40. Ieva, R., Tian, P., Peterson, J. H. and Bernstein, H. D. (2011) Sequential and spatially restricted interactions of assembly factors with an autotransporter beta domain. Proceedings of the National Academy of Sciences of the United States of America 108, E383-E391.

41. Jarchow, S., Luck, C., Gorg, A. and Skerra, A. (2008) Identification of potential substrate proteins for the periplasmic Escherichia coli chaperone Skp. Proteomics 8, 4987-4994.

42. Ruiz-Perez, F., Henderson, I. R., Leyton, D. L., Rossiter, A. E., Zhang, Y. H. and Nataro, J. P. (2009) Roles of Periplasmic Chaperone Proteins in the Biogenesis of Serine Protease Autotransporters of Enterobacteriaceae. Journal of Bacteriology 191, 6571-6583.

43. Denoncin, K., Schwalm, J., Vertommen, D., Silhavy, T. J. and Collet, J. F. (2012) Dissecting the Escherichia coli periplasmic chaperone network using differential proteomics. Proteomics 12, 1391-1401.

44. Volokhina, E. B., Grijpstra, J., Stork, M., Schilders, I., Tommassen, J. and Bos, M. P. (2011) Role of the Periplasmic Chaperones Skp, SurA, and DegQ in Outer Membrane Protein Biogenesis in Neisseria meningitidis. Journal of Bacteriology $193,1612-1621$.

45. Wagner, J. K., Heindl, J. E., Gray, A. N., Jain, S. and Goldberg, M. B. (2009) Contribution of the Periplasmic Chaperone Skp to Efficient Presentation of the Autotransporter IcsA on the Surface of Shigella flexneri. Journal of Bacteriology 191, 815-821.

46. Spiess, C., Beil, A. and Ehrmann, M. (1999) A temperature-dependent switch from chaperone to protease in a widely conserved heat shock protein. Cell 97, 339347.

47. Krojer, T., Garrido-Franco, M., Huber, R., Ehrmann, M. and Clausen, T. (2002) Crystal structure of DegP (HtrA) reveals a new protease-chaperone machine. Nature 416, 455-459.

48. Krojer, T., Sawa, J., Schafer, E., Saibil, H. R., Ehrmann, M. and Clausen, T. (2008) Structural basis for the regulated protease and chaperone function of DegP. Nature 453, 885-U831.

49. Jiang, J. S., Zhang, X. F., Chen, Y., Wu, Y., Zhou, Z. H., Chang, Z. and Sui, S. F. (2008) Activation of DegP chaperone-protease via formation of large cage-like oligomers upon binding to substrate proteins. Proceedings of the National Academy of Sciences of the United States of America 105, 11939-11944.

50. Sawa, J., Heuck, A., Ehrmann, M. and Clausen, T. (2010) Molecular transformers in the cell: lessons learned from the DegP protease-chaperone. Current Opinion in Structural Biology 20, 253-258. 
51. Kim, S., Grant, R. A. and Sauer, R. T. (2011) Covalent Linkage of Distinct Substrate Degrons Controls Assembly and Disassembly of DegP Proteolytic Cages. Cell 145, 67-78.

52. Thompson, N. J., Merdanovic, M., Ehrmann, M., van Duijn, E. and Heck, A. J. R. (2014) Substrate Occupancy at the Onset of Oligomeric Transitions of DegP. Structure 22, 281-290.

53. Kim, S. and Sauer, R. T. (2012) Cage assembly of DegP protease is not required for substrate-dependent regulation of proteolytic activity or high-temperature cell survival. Proceedings of the National Academy of Sciences of the United States of America 109, 7263-7268.

54. Ge, X., Wang, R., Ma, J., Liu, Y., Ezemaduka, A. N., Chen, P. R., Fu, X. and Chang, Z. (2013) DegP primarily functions as a protease for the biogenesis of beta-barrel outer membrane proteins in the Gram-negative bacterium Escherichia coli. Febs Journal.

55. Rizzitello, A. E., Harper, J. R. and Silhavy, T. J. (2001) Genetic evidence for parallel pathways of chaperone activity in the periplasm of Escherichia coli. Journal of Bacteriology 183, 6794-6800.

56. Chen, R. and Henning, U. (1996) A periplasmic protein (Skp) of Escherichia coli selectively binds a class of outer membrane proteins. Molecular Microbiology 19, 1287-1294.

57. Bos, M. P., Robert, V. and Tommassen, J. (2007) Biogenesis of the gram-negative bacterial outer membrane. Annual Review of Microbiology 61, 191-214.

58. Schwalm, J., Mahoney, T. F., Soltes, G. R. and Silhavy, T. J. (2013) A role for Skp in LptD assembly in Escherichia coli. J Bacteriol 195, 3734-3742.

59. Schwalm, J., Mahoney, T. F., Soltes, G. R. and Silhavy, T. J. (2013) Role for Skp in LptD Assembly in Escherichia coli. Journal of Bacteriology 195, 3734-3742.

60. Arie, J. P., Sassoon, N. and Betton, J. M. (2001) Chaperone function of FkpA, a heat shock prolyl isomerase, in the periplasm of Escherichia coli. Molecular Microbiology 39, 199-210.

61. Dartigalongue, C., Missiakas, D. and Raina, S. (2001) Characterization of the Escherichia coli sigma(E) regulon. Journal of Biological Chemistry 276, 2086620875.

62. Saul, F. A., Arie, J. P., Vulliez-le Normand, B., Kahn, R., Betton, J. M. and Bentley, G. A. (2004) Structural and functional studies of FkpA from Escherichia coli, a cis/trans peptidyl-prolyl isomerase with chaperone activity. Journal of Molecular Biology 335, 595-608.

63. Ruiz-Perez, F., Henderson, I. R. and Nataro, J. P. (2010) Interaction of FkpA, a peptidyl-prolyl cis/trans isomerase with EspP autotransporter protein. Gut Microbes 1, 339-344.

64. Martin, J. L., Bardwell, J. C. A. and Kuriyan, J. (1993) Crystal-Structure of the Dsba Protein Required for Disulfide Bond Formation in-Vivo. Nature 365, 464-468.

65. Hiniker, A. and Bardwell, J. C. A. (2004) In vivo substrate specificity of periplasmic disulfide oxidoreductases. Journal of Biological Chemistry 279, 1296712973.

66. Kadokura, H., Tian, H. P., Zander, T., Bardwell, J. C. A. and Beckwith, J. (2004) Snapshots of DsbA in action: Detection of proteins in the process of oxidative folding. Science (New York, N.Y.) 303, 534-537.

67. Negoda, A., Negoda, E. and Reusch, R. N. (2010) Resolving the native conformation of Escherichia coli OmpA. Febs Journal 277, 4427-4437. 
68. Brandon, L. D. and Goldberg, M. B. (2001) Periplasmic transit and disulfide bond formation of the autotransported Shigella protein IcsA. Journal of Bacteriology 183, 951-958.

69. Chng, S. S., Xue, M., Garner, R. A., Kadokura, H., Boyd, D., Beckwith, J. and Kahne, D. (2012) Disulfide rearrangement triggered by translocon assembly controls lipopolysaccharide export. Science (New York, N.Y.) 337, 1665-1668.

70. Kadokura, H. and Beckwith, J. (2009) Detecting Folding Intermediates of a Protein as It Passes through the Bacterial Translocation Channel. Cell 138, 11641173.

71. Rietsch, A., Belin, D., Martin, N. and Beckwith, J. (1996) An in vivo pathway for disulfide bond isomerization in Escherichia coli. Proceedings of the National Academy of Sciences of the United States of America 93, 13048-13053.

72. McCarthy, A. A., Haebel, P. W., Torronen, A., Rybin, V., Baker, E. N. and Metcalf, P. (2000) Crystal structure of the protein disulfide bond isomerase, DsbC, from Escherichia coli. Nature Structural Biology 7, 196-199.

73. Missiakas, D., Schwager, F. and Raina, S. (1995) Identification and Characterization of a New Disulfide Isomerase-Like Protein (Dsbd) in EscherichiaColi. Embo Journal 14, 3415-3424.

74. Heras, B., Shouldice, S. R., Totsika, M., Scanlon, M. J., Schembri, M. A. and Martin, J. L. (2009) DSB proteins and bacterial pathogenicity. Nature Reviews Microbiology 7, 215-225.

75. Totsika, M., Heras, B., Wurpel, D. J. and Schembri, M. A. (2009) Characterization of Two Homologous Disulfide Bond Systems Involved in Virulence Factor Biogenesis in Uropathogenic Escherichia coli CFT073. Journal of Bacteriology 191, 3901-3908.

76. Arts, I. S., Ball, G., Leverrier, P., Garvis, S., Nicolaes, V., Vertommen, D., Ize, B., Dufe, V. T., Messens, J., Voulhoux, R. and Collet, J. F. (2013) Dissecting the Machinery That Introduces Disulfide Bonds in Pseudomonas aeruginosa. Mbio 4.

77. Reusch, R. N. (2012) Insights into the structure and assembly of Escherichia coli outer membrane protein A. Febs Journal 279, 894-909.

78. Ge, X., Lyu, Z. X., Liu, Y., Wang, R., Zhao, X. S., Fu, X. and Chang, Z. (2014) Identification of FkpA as a key quality control factor for the biogenesis of outer membrane proteins under heat shock conditions. J Bacteriol 196, 672-680.

79. Roux, A., Beloin, C. and Ghigo, J. M. (2005) Combined inactivation and expression strategy to study gene function under physiological conditions: Application to identification of new Escherichia coli adhesins. Journal of Bacteriology 187, 1001-1013.

80. Murphy, K. C. (1998) Use of bacteriophage lambda recombination functions to promote gene replacement in Escherichia coli. Journal of Bacteriology 180, 20632071.

81. Datsenko, K. A. and Wanner, B. L. (2000) One-step inactivation of chromosomal genes in Escherichia coli K-12 using PCR products. Proceedings of the National Academy of Sciences of the United States of America 97, 6640-6645.

82. Veiga, E., de Lorenzo, V. and Fernández, L. A. (1999) Probing secretion and translocation of a beta-autotransporter using a reporter single-chain $\mathrm{Fv}$ as a cognate passenger domain. Molecular Microbiology 33, 1232-1243.

83. Cherepanov, P. P. and Wackernagel, W. (1995) Gene Disruption in EscherichiaColi - Tcr and Km(R) Cassettes with the Option of Flp-Catalyzed Excision of the Antibiotic-Resistance Determinant. Gene 158, 9-14. 
84. Jurado, P., Ritz, D., Beckwith, J., de Lorenzo, V. and Fernández, L. A. (2002) Production of functional single-chain Fv antibodies in the cytoplasm of Escherichia coli. J Mol Biol 320, 1-10.

85. Palomino, C., Marín, E. and Fernández, L. Á. (2011) The Fimbrial Usher FimD Follows the SurA-BamB Pathway for Its Assembly in the Outer Membrane of Escherichia coli. J. Bacteriol. 193, 5222-5230.

86. Nakamura, K. and Mizushima, S. (1976) Effects of heating in dodecyl sulfate solution on the conformation and electrophoretic mobility of isolated major outer membrane proteins from Escherichia coli K-12. J Biochem 80, 1411-1422.

87. Schweizer, M., Hindennach, I., Garten, W. and Henning, U. (1978) Major proteins of the Escherichia coli outer cell envelope membrane. Interaction of protein II with lipopolysaccharide. Eur J Biochem 82, 211-217.

88. Fairman, J. W., Dautin, N., Wojtowicz, D., Liu, W., Noinaj, N., Barnard, T. J., Udho, E., Przytycka, T. M., Cherezov, V. and Buchanan, S. K. (2012) Crystal structures of the outer membrane domain of intimin and invasin from enterohemorrhagic E. coli and enteropathogenic Y. pseudotuberculosis. Structure 20, 1233-1243.

89. Kenny, B., DeVinney, R., Stein, M., Reinscheid, D. J., Frey, E. A. and Finlay, B. B. (1997) Enteropathogenic E. coli (EPEC) transfers its receptor for intimate adherence into mammalian cells. Cell 91, 511-520.

90. Frankel, G., Candy, D. C. A., Everest, P. and Dougan, G. (1994) Characterization of the C-Terminal Domains of Intimin-Like Proteins of Enteropathogenic and Enterohemorrhagic Escherichia-Coli, Citrobacter-Freundii, and Hafnia-Alvei. Infection and Immunity 62, 1835-1842.

91. Frankel, G., Candy, D. C., Everest, P. and Dougan, G. (1994) Characterization of the C-terminal domains of intimin-like proteins of enteropathogenic and enterohemorrhagic Escherichia coli, Citrobacter freundii, and Hafnia alvei. Infect Immun 62, 1835-1842.

92. Batchelor, M., Prasannan, S., Daniell, S., Reece, S., Connerton, I., Bloomberg, G., Dougan, G., Frankel, G. and Matthews, S. (2000) Structural basis for recognition of the translocated intimin receptor (Tir) by intimin from enteropathogenic Escherichia coli. Embo Journal 19, 2452-2464.

93. Yu, L., Frey, E. A., Pfuetzner, R. A., Creagh, A. L., Knoechel, D. G., Haynes, C. A., Finlay, B. B. and Strynadka, N. C. J. (2000) Crystal structure of enteropathogenic Escherichia coli intimin-receptor complex. Nature 405, 1073-1077.

94. Veiga, E., de Lorenzo, V. and Fernández, L. A. (2004) Structural tolerance of bacterial autotransporters for folded passenger protein domains. Molecular Microbiology 52, 1069-1080.

95. Garmendia, J., Phillips, A. D., Carlier, M. F., Chong, Y. W., Schuller, S., Marches, O., Dahan, S., Oswald, E., Shaw, R. K., Knutton, S. and Frankel, G. (2004) TccP is an enterohaemorrhagic Escherichia coli 0157 : H7 type III effector protein that couples Tir to the actin-cytoskeleton. Cellular Microbiology 6, 1167-1183.

96. Donnenberg, M. S. and Kaper, J. B. (1991) Construction of an Eae Deletion Mutant of Enteropathogenic Escherichia-Coli by Using a Positive-Selection Suicide Vector. Infection and Immunity 59, 4310-4317.

97. Frankel, G., Phillips, A. D., Novakova, M., Field, H., Candy, D. C. A., Schauer, D. B., Douce, G. and Dougan, G. (1996) Intimin from enteropathogenic Escherichia coli restores murine virulence to a Citrobacter rodentium eaeA mutant: Induction of an immunoglobulin a response to intimin and EspB. Infection and Immunity 64, 53155325. 
98. Lee, C. (2007) Western Blotting, in Circadian Rhythms, vol. 362: Methods in Molecular Biology (E. Rosato ed) Humana Press: pp. 391-399.

99. Schagger, H. and von Jagow, G. (1991) Blue native electrophoresis for isolation of membrane protein complexes in enzymatically active form. Anal Biochem 199, 223-231.

100. Touze, T., Hayward, R. D., Eswaran, J., Leong, J. M. and Koronakis, V. (2004) Self-association of EPEC intimin mediated by the b-barrel-containing anchor domain: a role in clustering of the Tir receptor. Mol Microbiol 51, 73-87.

101. Marín, E., Bodelón, G. and Fernández, L. A. (2010) Comparative Analysis of the Biochemical and Functional Properties of C-Terminal Domains of Autotransporters. Journal of Bacteriology 192, 5588-5602.

102. Munera, D., Hultgren, S. and Fernández, L. A. (2007) Recognition of the Nterminal lectin domain of FimH adhesin by the usher FimD is required for type 1 pilus biogenesis. Molecular Microbiology 64, 333-346.

103. Jurado, P., Ritz, D., Beckwith, J., de Lorenzo, V. and Fernández, L. A. (2002) Production of functional single-chain Fv antibodies in the cytoplasm of Escherichia coli. Journal of Molecular Biology 320, 1-10. 


\section{Figure Legends}

Figure 1. Construction of SurA depletion $\boldsymbol{E}$. coli mutant strain. (A) Scheme of the RExBAD casette amplified by PCR from the TG1zeoRExBAD strain using primers ZEOBAD SurA1 and ZEOBAD SurA2 and insertion of the RExBAD cassette by $\lambda$ red-driven homologous recombination after transformation with the PCR product containing the zeoRExBAD cassette and flanking DNA of the surA promoter region. (B) Schematic of $\mathrm{P}_{\mathrm{BAD}}$ controlled surA allele in the $\mathrm{UTP}_{\mathrm{BAD}}:$ :surA strain.

Figure 2. Expression of FimD in the conditional $E$. coli surA mutant. (A) Growth curves of static cultures of $\mathrm{UTP}_{\mathrm{BAD}}$ ::surA strain grown in rich BHI medium containing D-glucose (Glu) or L-arabinose (Ara) and maintained in exponential phase by repeated dilutions with the same medium. Samples from these cultures were taken at the indicated times (I, II, and III) for Western blot analysis. (B) Whole-cell protein extracts from bacteria harvested at the indicated times (I, II, and III) from cultures shown in panel A were analyzed by Western blotting with anti-FimD, anti-OmpA, anti-SurA, anti-Skp, anti-DegP, and anti-GroEL antibodies. Control samples were obtained from cultures of UTP $\mathrm{BAD}_{\mathrm{B}}:$ surA grown in medium with L-arabinose. Reproduced from (85) with permission from ASM.

Figure 3. Intimin domain organization and expression in EPEC (E2348/69) and $\boldsymbol{E}$. coli K-12. (A) Schematic drawing of intimin illustrating its domain organization. The first 550 amino acid residues of intimin (Int550) contain a signal peptide ( $\mathrm{sp}$ ) located at the $\mathrm{N}$ terminus $(\mathrm{N})$, a putative peptidoglycan-binding domain (LysM), and an OM-embedded domain predicted to fold as a $\beta$-barrel. The immunoglobulin-like (D0, D1, and D2) and the lectin-like (D3) domains are displayed on the bacterial surface. Domain D3 contains a disulfide bond indicated with an "S-S". (B) Western blotting performed with a rabbit anti-Int $280_{\text {EPEC }}$ polyclonal serum (detecting domains D1, D2, and D3) of whole-cell protein extracts from EPEC bacteria grown in LB in the presence $(+)$ or absence $(-)$ of 10 mM 2-ME. Intact bacteria, harvested from this culture, were incubated with $(+)$ or without (-) PK. The whole-cell extracts were prepared in urea-SDS sample buffer $(2 \%$ SDS, $4 \mathrm{M}$ urea) and boiled $(+)$ or not $(-)$ as indicated. The mobility of unfolded (U) and folded (F) intimin is labeled on the right, and the masses of protein standards are shown on the left (in kilodaltons). (C) Western blot probed with anti-Int280 $0_{\mathrm{EPEC}}$ of whole-cell protein extracts from E. coli K-12 strain UT5600 carrying pCVD438. Reproduced from (27) with permission from ASM.

Figure 4. Intimin expression in a $d s b A$ mutant of $E$. coli $\mathrm{K}-12$ and PK sensitivity. Western blot with anti-Int280 ${ }_{\mathrm{EPEC}}$ of whole-cell protein extracts in urea-SDS sample buffer of E. coli UT5600 and its isogenic $d s b A$ mutant carrying pCVD438. Samples were treated as in Figure 3. Reproduced from (27) with permission from ASM. 
Figure 5. Alkylation with mPEG-MAL of intimin expressed in EPEC, UT5600/pCVD438 and UTdsbA/pCVD438. Treated samples were subjected to non-reducing SDS-PAGE and Western blotting developed with anti-Int280 2 EPEC serum. Samples incubated with the reducing agent DTT and/or with the alkylating agent mPEG-MAL are indicated (+). The bands corresponding to alkylated intimin polypeptide are labeled with arrows. The masses of protein standards are shown on the left (in $\mathrm{kDa}$ ). Reproduced from (27) with permission from ASM.

Figure 6. Outer membrane localization and dimerization of intimin polypeptides. Blue-native PAGE of solubilized OMPs from the outer membrane fractions of E. coli UT5600/pInt550, UT5600/pNeae and EPEC bacteria. Intimin polypeptides were detected by Western blot incubating the membrane with antiInt $280_{\mathrm{EPEC}}$ serum followed by incubation with a mixture of protein A-POD and antiE-tag mAb-POD. The mass of native protein standards (GE Amersham) is shown on the left (in $\mathrm{kDa}$ ). Reproduced from (27) with permission from ASM.

Figure 7. Analysis of the quaternary structure of the AT C-terminal domains in vivo. (A) Cross-linking with DSP of ATs C-terminal domains expressed in E. coli to determine the formation of oligomeric complexes in vivo. DSP-treated $(+)$ and untreated $(-)$ samples were subjected to non-reducing SDS-PAGE, and the Western blot was probed with anti-E tag mAb-POD. Samples incubated with the reducing agent 2-ME are indicated (+). (B) Samples treated as in A but subjected to reducing SDS-PAGE. Reproduced from (101) with permission from ASM. 
Figure 1

A
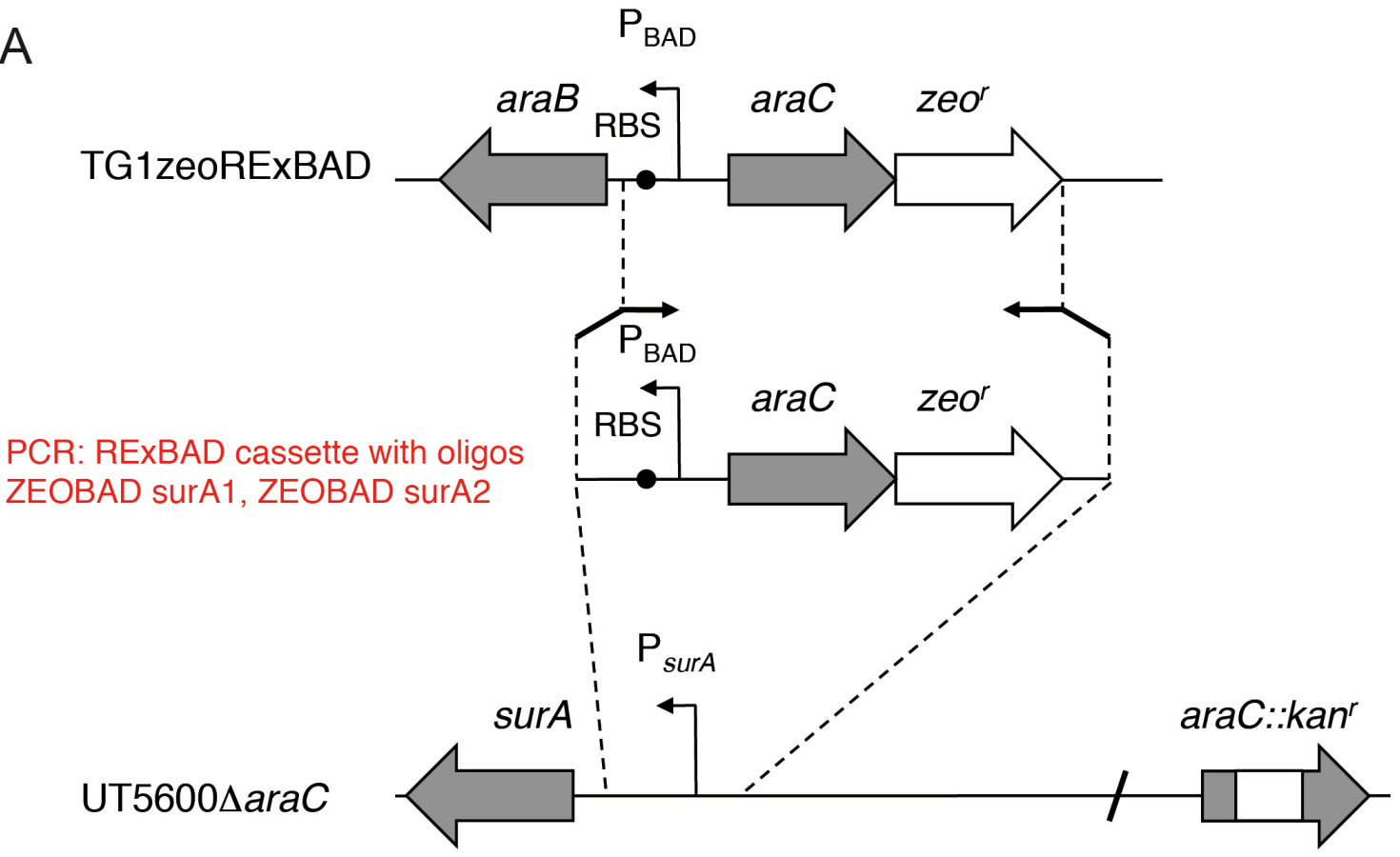

B

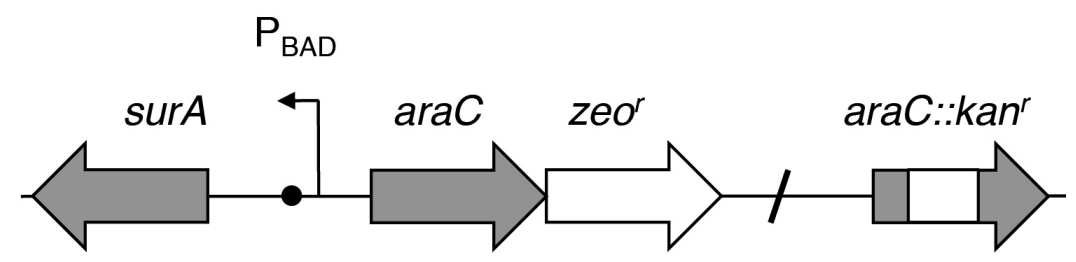


Figure 2

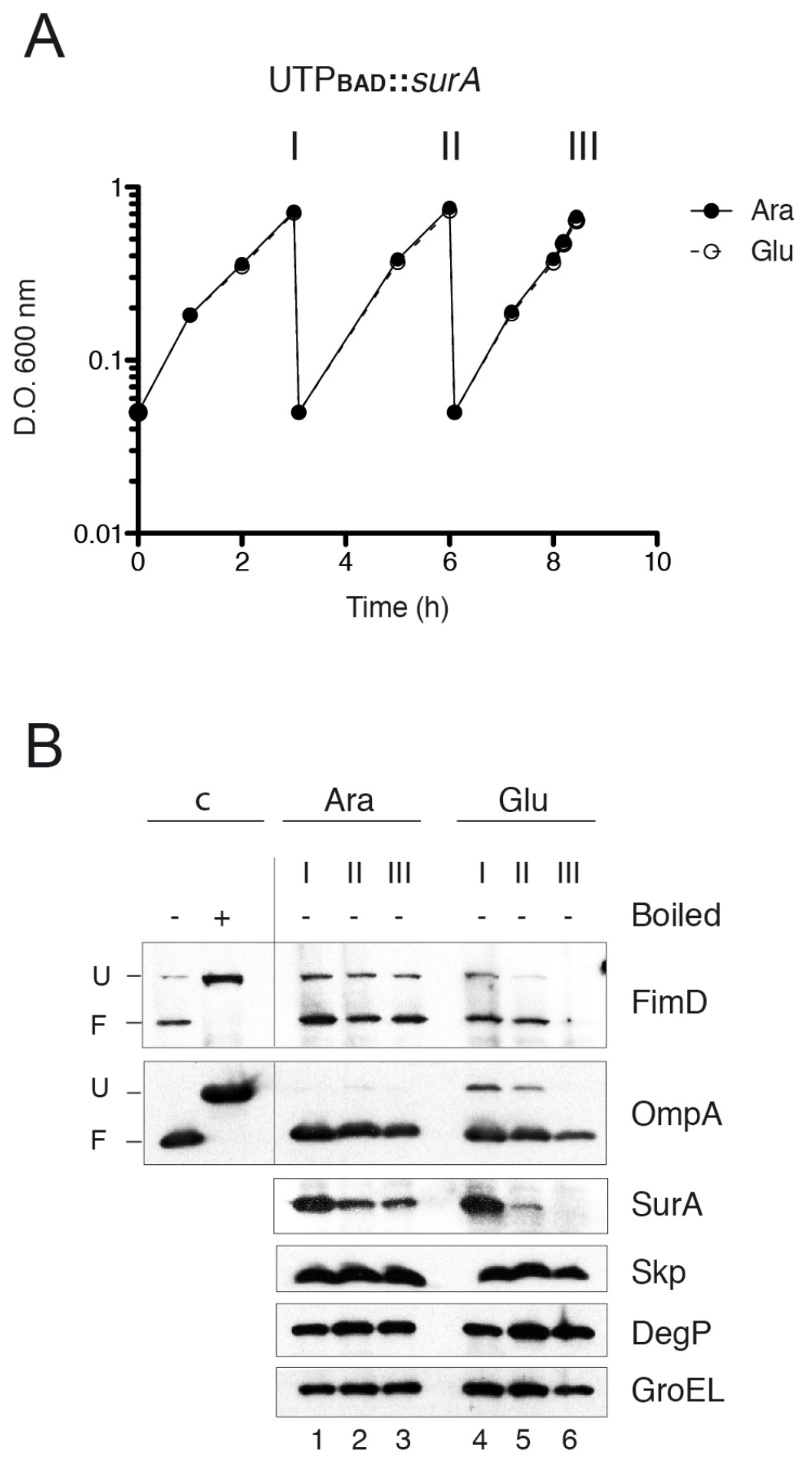


Figure 3

A

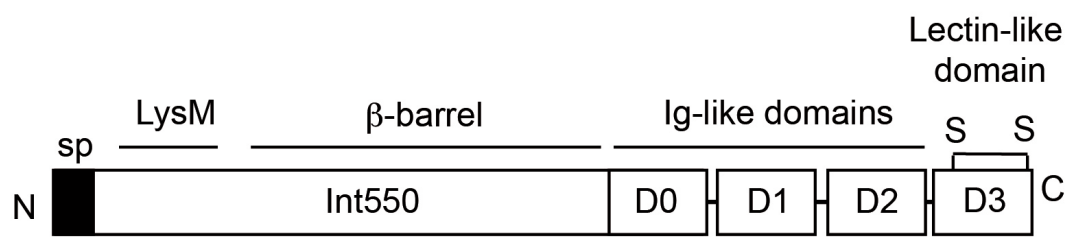

B

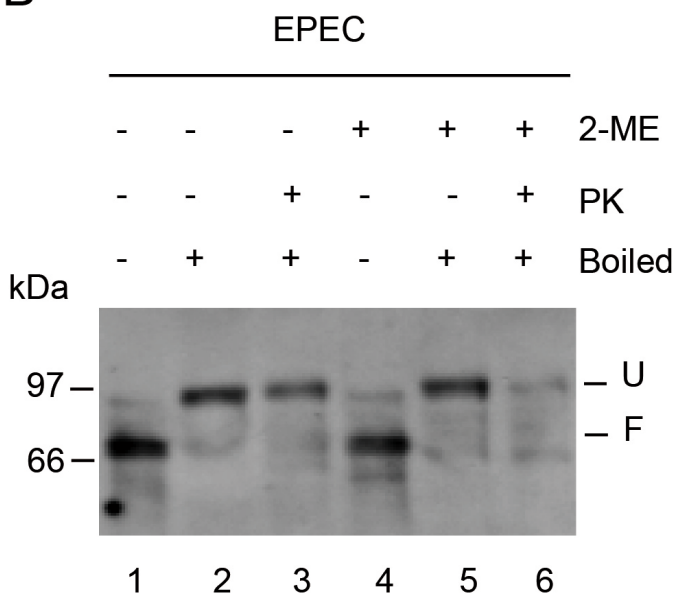

C

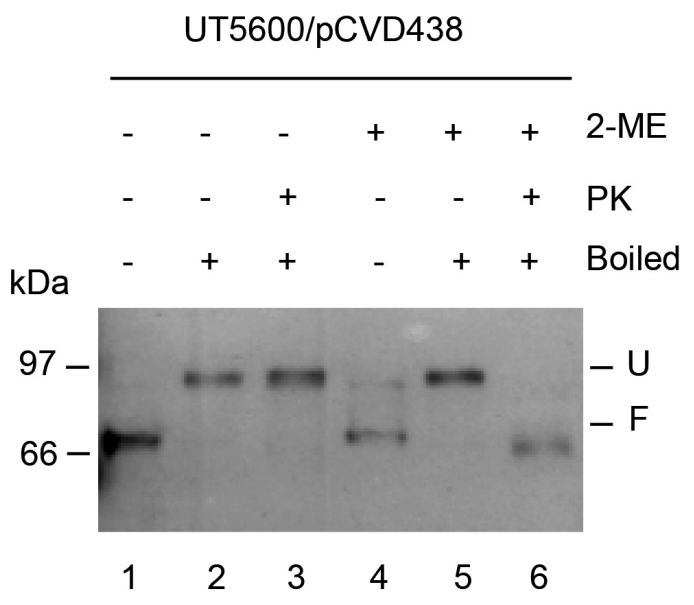


Figure 4

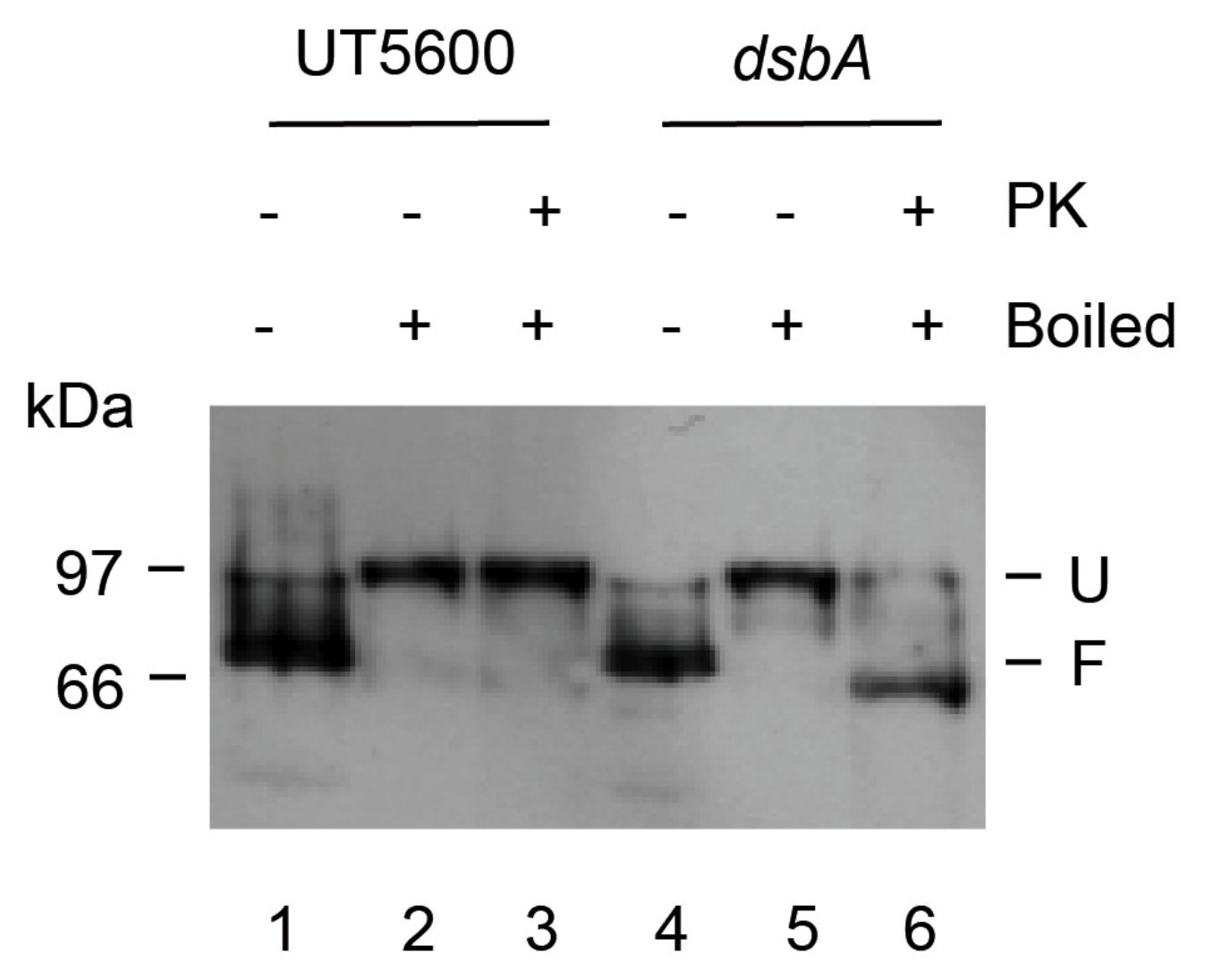


Figure 5

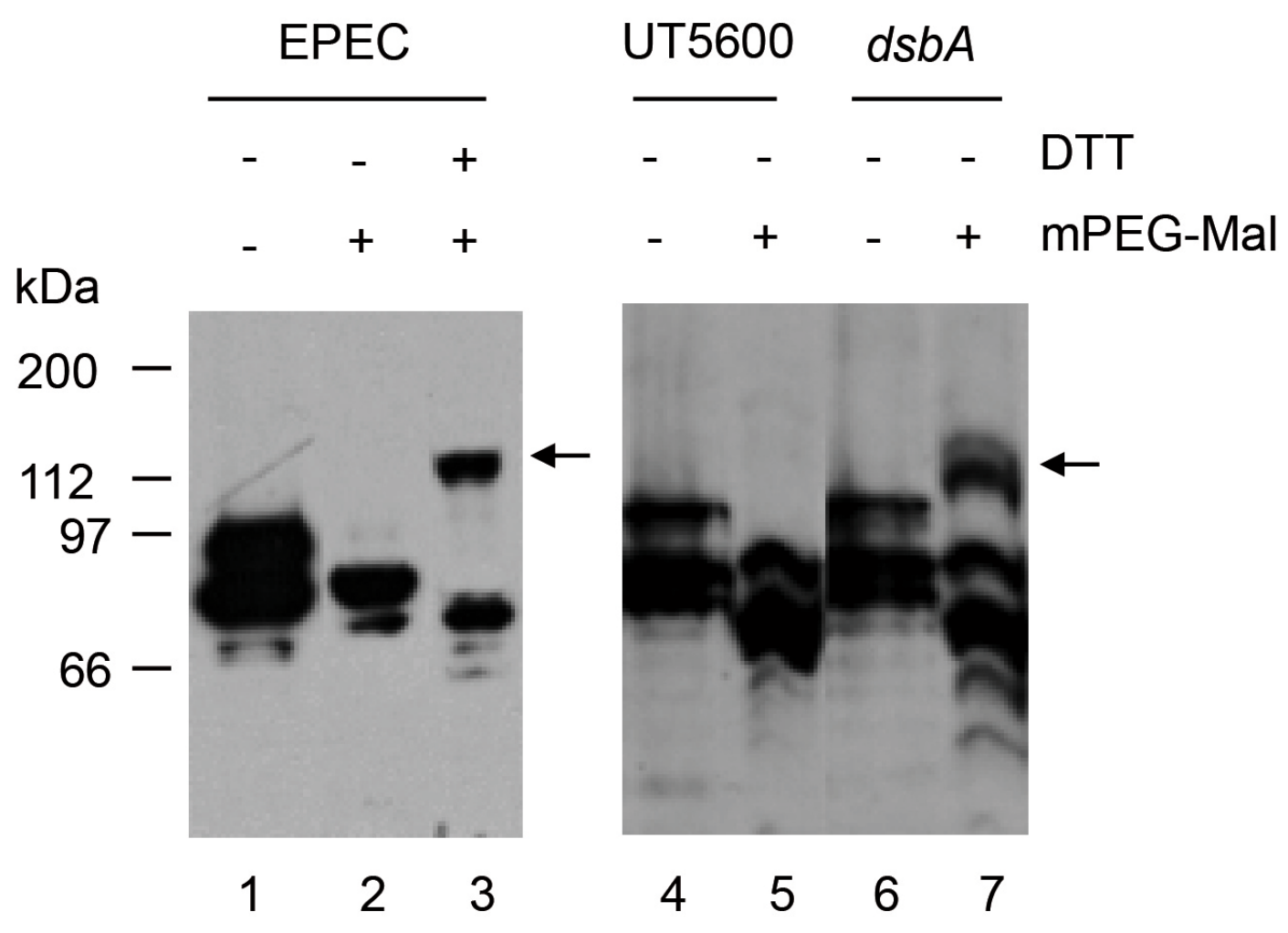




\section{Figure 6}

kDa M Int550 Neae Intimin

669-

440-

232-

140-

66- 
Figure 7

A

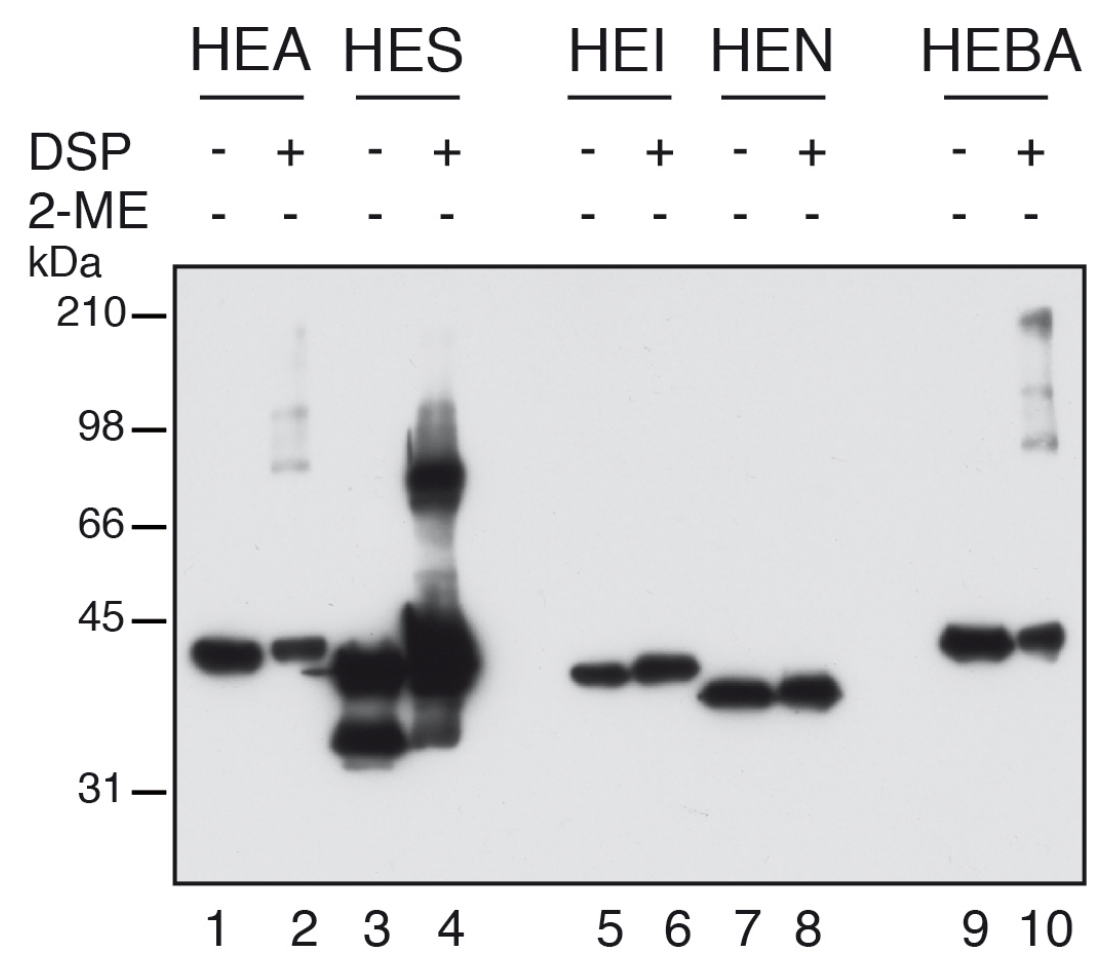

B

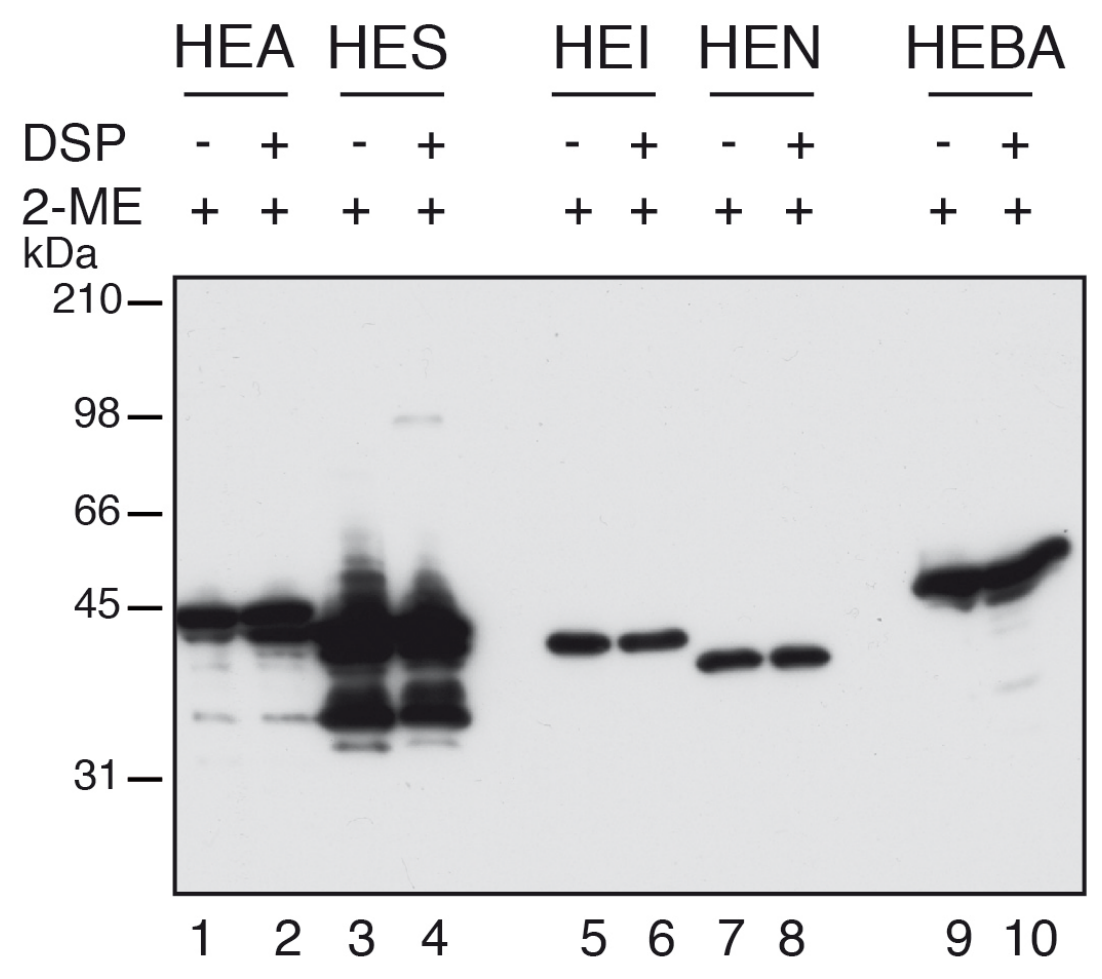

